
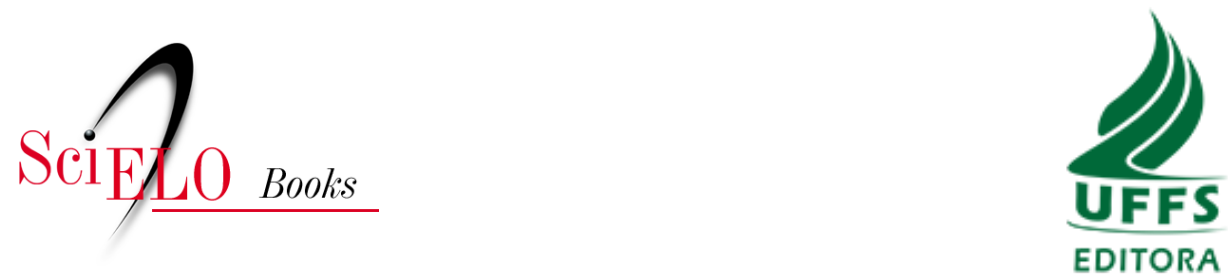

\title{
Perfil socioeconômico e a trajetória escolar dos ingressantes na UFFS
}

\author{
Rosileia Lucia Nierotka \\ Joviles Vitório Trevisol
}

\section{SciELO Books / SciELO Livros / SciELO Libros}

NIEROTKA, R.L., and TREVISOL, J.V. Perfil socioeconômico e a trajetória escolar dos ingressantes na UFFS. In: Ações afirmativas na educação superior: a experiência da Universidade Federal da Fronteira Sul [online]. Chapecó: Editora UFFS, 2019, pp. 95-157. ISBN: 978-655019-009-5. https://doi.org/10.7476/9786550190071.0005.

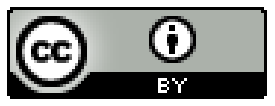

All the contents of this work, except where otherwise noted, is licensed under a Creative Commons Attribution 4.0 International license.

Todo o conteúdo deste trabalho, exceto quando houver ressalva, é publicado sob a licença Creative Commons Atribição 4.0. 


\title{
PERFIL SOCIOECONÔMICO E A TRAJETÓRIA ESCOLAR DOS INGRESSANTES NA UFFS
}

\begin{abstract}
A democratização do acesso à educação superior está profundamente relacionada às precárias condições socioeconômicas de parcela majoritária dos nossos jovens. Em um país tão desigual como o Brasil, os jovens sofrem consequências particulares dessa desigualdade - como a baixa escolarização;

a dificuldade para entrar e permanecer no ensino médio; e as enormes barreiras para entrar e permanecer no ensino superior. Diante desse quadro, é impossível pensar em uma democratização do acesso para a imensa maioria dos jovens brasileiros sem a intervenção de políticas públicas específicas.
\end{abstract}

Dilvo Risttof

Neste capítulo serão apresentados os resultados da análise realizada a partir do questionário socioeconômico do Processo Seletivo de 2012 e de outras questões complementares ao questionário. Primeiramente, será apresentada uma caracterização do perfil socioeconômico e a trajetória escolar dos ingressantes em 2012 nos cinco campi $i^{1}$ da UFFS; em seguida, será realizada uma explanação sobre a situação de matrícula dos estudantes, enfatizando aspectos relacionados a permanência ou não na Universidade, após um período de dois anos do seu ingresso.

1 Importante ressaltar que essa análise abrange o Campus Passo Fundo, pois este foi criado em 2013. 


\section{PERFIL SOCIOECONÔMICO}

A caracterização do perfil socioeconômico dos estudantes da UFFS será apresentada com base nas seguintes variáveis: sexo; faixa etária; etnia; trabalho e renda familiar dos ingressantes. Os dados serão analisados sempre de forma comparativa com outros dados, de forma a qualificar essa temática no âmbito local, regional e nacional.

\section{Sexo}

Ao analisar os dados referentes aos estudantes da UFFS, constatou-se que a presença feminina é majoritária, correspondendo a $63,5 \%$ do total dos ingressantes no ano de 2012.

Ao olhar para os diferentes campi da UFFS, observa-se que o percentual de mulheres é maior em todos, principalmente nos campi Cerro Largo e Erechim, próximo ao dobro dos homens, como demonstra o gráfico a seguir.

Gráfico 6 - Percentual de ingressantes por campus, segundo o sexo

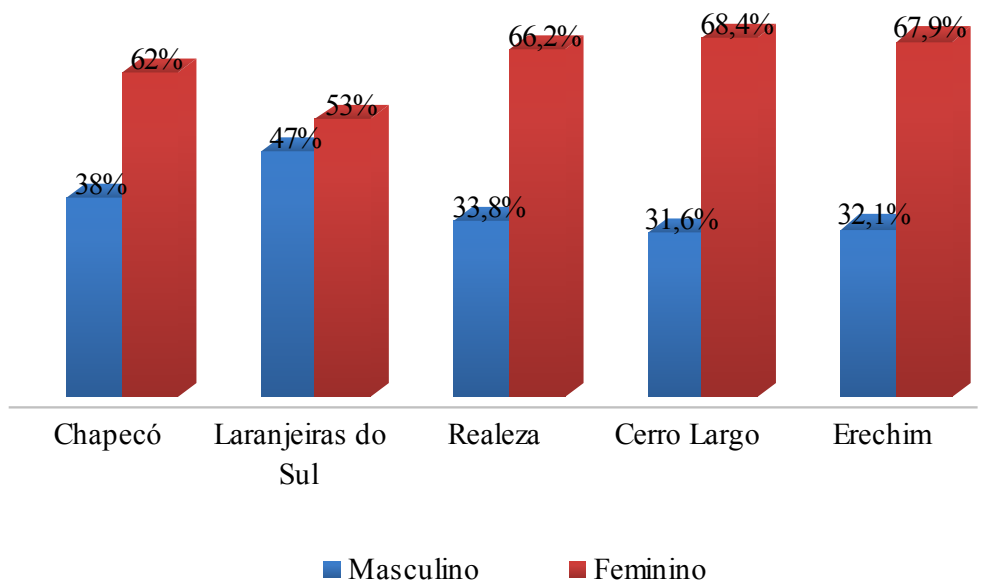

Fonte: Banco de Dados do Processo Seletivo 2012, DRA/PROGRAD/UFFS.

Outra possibilidade de análise com relação à presença feminina e masculina na UFFS foi nos cursos frequentados pelos ingressantes, conforme 
demonstra o próximo gráfico. Percebeu-se que as mulheres representam a maioria em determinadas áreas, principalmente nas licenciaturas, mais especificamente nos cursos de Pedagogia (Campus Chapecó e Erechim) e Letras (Campus Chapecó, Realeza e Cerro Largo) e na área de saúde, nos cursos de Enfermagem (Campus Chapecó) e Nutrição (Campus Realeza). Esses últimos se apresentam com um percentual de $100 \%$ de mulheres.

A presença masculina se destaca principalmente nos cursos de Ciência da Computação (Campus Chapecó), Engenharia de Aquicultura (Campus Laranjeiras do Sul), Agronomia (Campus de Chapecó, Cerro Largo, Erechim e Laranjeiras do Sul), Ciências Econômicas (Campus Laranjeiras do Sul) e Medicina Veterinária (Campus Realeza).

A presença feminina nos cursos de graduação da UFFS é superior ao verificado nas IES da Região Sul e do Brasil. De acordo com a pesquisa realizada pela Andifes/Fonaprace ${ }^{2}$ (2011), o feminino representa a maioria, correspondendo a 53,5\%, e, na Região Sul, os dados indicaram um percentual de $50,5 \%$.

Os resultados do Censo da Educação Superior do ano de 2012, com relação às matrículas realizadas na educação superior naquele ano, demonstraram um percentual feminino de $55,5 \%$ e masculino de $44,5 \%$ (MEC/INEP, 2013b).

De acordo com Ristoff (2013a), a presença feminina na educação vem se firmando ao longo dos anos, desde o ensino fundamental. Servindo-se da base de dados do INEP, o autor demonstra que, desde 1991, o percentual de mulheres é maior. A média no período entre 2002 a 2011 é de 57\%.

Em outro estudo sobre a mulher na educação superior brasileira, referente ao período de 1991 a 2005, Ristoff et al. (2007) afirmam que a presença feminina é maior, tanto nas taxas de matrículas, quanto nas taxas dos concluintes, nas quais é ainda superior, chegando a uma diferença de até 25 pontos percentuais.

2 Refere-se à pesquisa, intitulada: "Perfil Socioeconômico e Cultural dos estudantes de graduação das universidades federais brasileiras", realizada em 2010, cujo relatório com os resultados foi publicado em 2011. 


\section{Gráfico 7 - Percentual de ingressantes, segundo sexo e curso}

Ciência da Computação (B) Noturno

Ciência da Computação (B) Matutino

Engenharia de Aquicultura (B) Integral

Agronomia (B) Integral

Ciências Econômicas (B) Notuno

Medicina Veterinária (B) Integral Administração (B) Noturno

Geografia (L) Matutino História (L) Noturno

Geografia (L) Noturno

Interdiscip linar em Educação no Campo (L) Diurno

História (L) Matutino

ngenharia Ambiental e Energias Renováveis (B) Integral

Filosofia (L) Noturno

Ciências Sociais (L) Noturno

Administração (B) Integral

Ciências: Biologia, Física e Química (L) Noturno

Ciências Sociais (L) Matutino

Interdiscip linar em Educação no Campo (L) Noturno

Administração (B) Matutino

Arquitetura e Urbanismo (B) Integral

Letras - português e espanhol (L) - Matutino

Engenharia de Alimentos (B) Integral

Filosofia (L) Matutino

Letras - português e espanhol (L) Noturno

Pedagogia (L) Noturno

Enfermagem - (B) Integral

Pedagogia (L) Matutino

Nutrição (B) Integral
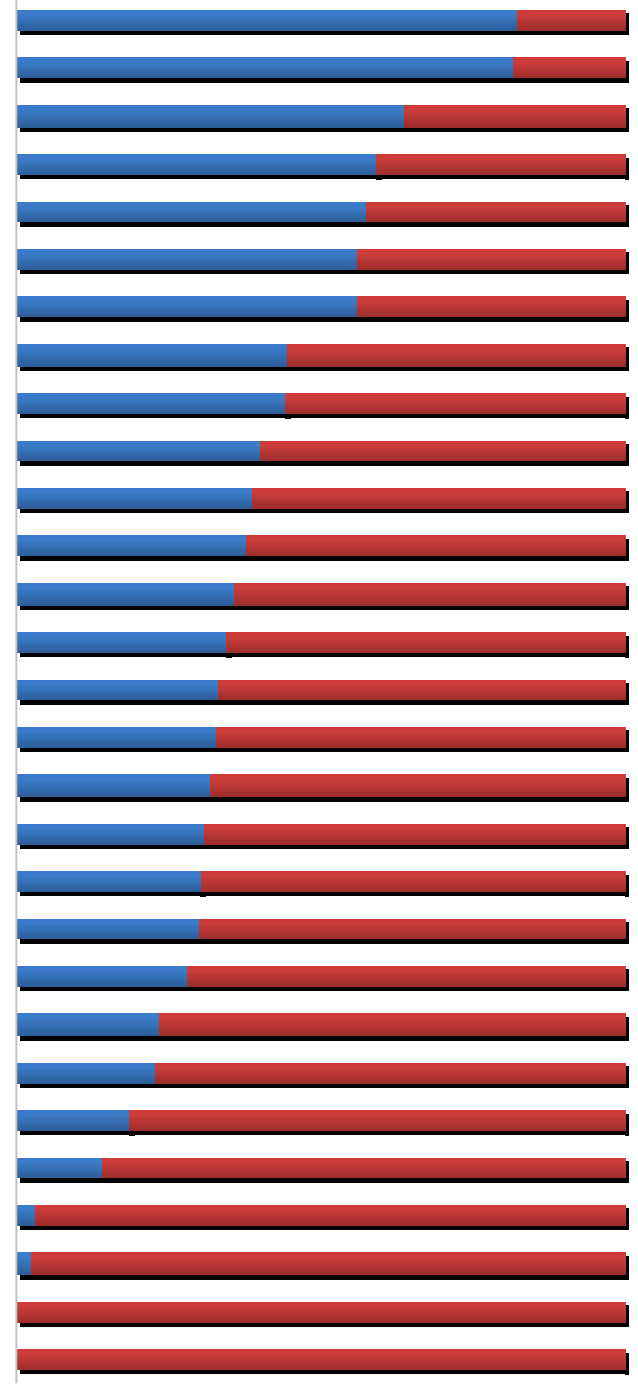

$\begin{array}{lllllllllll}0 \% & 10 \% & 20 \% & 30 \% & 40 \% & 50 \% & 60 \% & 70 \% & 80 \% & 90 \% & 100\end{array}$

- Masculino $\quad$ Feminino

Fonte: Banco de Dados do Processo Seletivo 2012, DRA/PROGRAD/UFFS.

Nota: $(\mathrm{B})=$ bacharelado; $(\mathrm{L})=$ licenciatura 
Com relação aos cursos de graduação, os autores chamam a atenção para a correlação entre a participação feminina no ensino superior e a divisão sexual do trabalho presente na sociedade, pois "[...] foram se constituindo as clássicas divisões entre o que se convencionou chamar de áreas mais 'femininas', concentradas nas ciências humanas e em vários cursos da área da saúde, e aquelas, ditas 'masculinas', mais presentes nas ciências exatas e nas carreiras tecnológicas" (RISTOFF et al., 2007, p. 10). Na UFFS, foi possível perceber essa relação entre a participação feminina e masculina, a partir dessa divisão sexual do trabalho.

Conforme o Censo da Educação Superior de 2012, as áreas de "Saúde e Bem-estar Social" estão entre os cursos mais procurados pelas mulheres e as áreas de "Engenharia, Produção e Construção" e "Ciências, Matemática e Computação" estão entre os cursos mais procurados pelos homens, na educação superior brasileira (MEC/INEP, 2014a, p. 69). Os dados também registram que as Regiões Sul e Centro-Oeste possuem maior participação de homens na área de "Agricultura e Veterinária", o que as diferem das demais regiões.

Para Ferraro (2010, p. 511), se houve alterações em relação à mulher e à escola,

[...] essa mudança certamente tem a ver não com sexo (com os aspectos biológicos que distinguem homens e mulheres), mas com gênero (com as mudanças nas concepções e valores a respeito da mulher e de seu lugar e papel na sociedade, assim como nas relações sociais entre homens e mulheres).

Segundo Lázaro et al. (2012), outra possibilidade de olhar para essa questão e, principalmente, para os motivos dessa forma diferenciada de acesso à educação superior dos homens em relação às mulheres, como fenômeno que também está presente em outros países, é a associação com a violência que atinge o sexo masculino. Os autores indicam que as causas dessas distorções 
podem estar relacionadas ao crescimento da mortalidade juvenil por causas externas, pois conforme aponta o Mapa da Violência no Brasil ${ }^{3}$,

[...] que analisou as mortes violentas entre jovens na faixa etária de 15 a 24 anos, no período de 1998 a 2008, constatou que o número de homicídios de jovens cresceu vertiginosamente. A maioria dos jovens assassinados é do sexo masculino (92\%) e, dentro desse universo, os negros são os mais atingidos, numa proporção de 103\%, ou seja, para cada jovem branco assassinado, morre mais do que o dobro de negros (LÁZARO et al., 2012, p. 7).

Em termos da população geral no Brasil e na Região Sul, a PNAD 2012 mostra que o percentual feminino é superior, conforme demonstra o próximo gráfico, de forma comparativa com a UFFS (IBGE, 2014).

Gráfico 8 - Percentual da população do Brasil, Região Sul e dos estudantes da UFFS, conforme o sexo

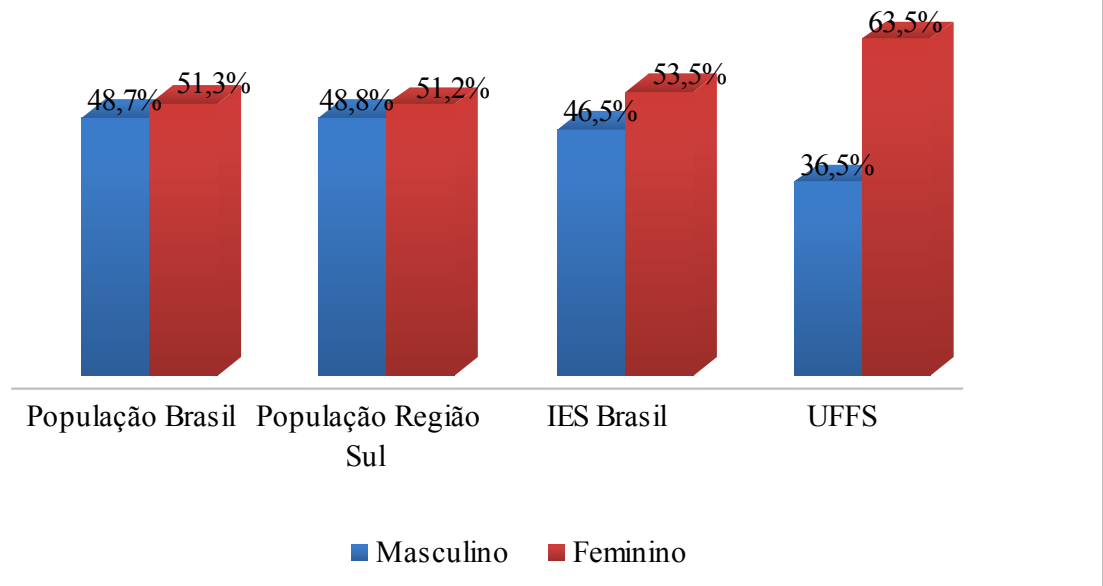

Fonte: Banco de Dados do Processo Seletivo 2012, DRA/PROGRAD/UFFS e IBGE (2014).

3 Conforme os autores, o referido Mapa foi elaborado pelo pesquisador Julio Jacobo Waiselfisz. Pode ser acessado em: http://www.mapadaviolencia.org.br/. 


\section{Faixa etária}

A faixa etária de 18 a 24 anos é compreendida como a faixa esperada para que os jovens estejam cursando a educação superior. Na UFFS, ao comparar os dados da faixa etária ${ }^{4}$ com dados em nível nacional e regional (gráfico 9), observou-se que há um contingente significativo de estudantes na faixa etária esperada para o ingresso na educação superior, representado por $71,5 \%$.

Gráfico 9 - Idade dos estudantes na UFFS e nas IES do Brasil e da Região Sul, em 2012

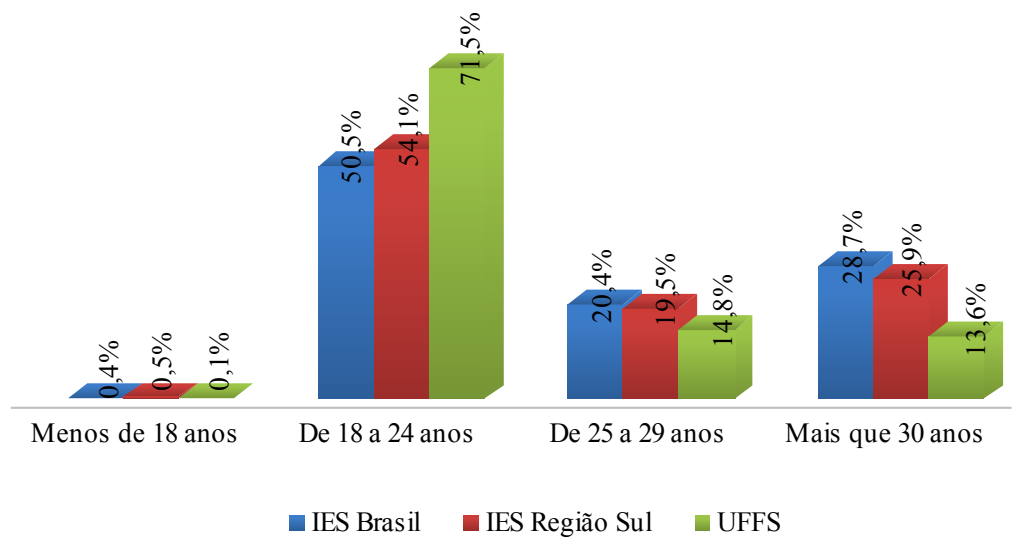

Fonte: Banco de Dados do Processo Seletivo 2012, DRA/PROGRAD/UFFS e MEC/INEP (2014b).

No gráfico 10, buscou-se analisar os dados da faixa etária dos estudantes em cada campus da UFFS 5 . Observou-se que, em todos os campi, mais de $65 \%$ dos ingressantes encontram-se na faixa etária de até 24 anos, chegando a 79,4\%, como é o caso do Campus Cerro Largo. Os campi Erechim e Chapecó possuem os maiores percentuais de estudantes acima de 24 anos de idade, $34,6 \%$ e $31,5 \%$, respectivamente.

4 Os dados sobre a idade dos estudantes foram organizados por faixas etárias.

5 Para esse gráfico as variáveis "menos de 18 anos" e "de 18 a 24 anos" foram agrupadas em numa única variável denominada "até 24 anos". Esse ajuste ocorreu devido à existência de apenas dois estudantes com menos de 18 anos, no Campus Chapecó. 
Gráfico 10 - Faixa etária dos estudantes da UFFS, por campus

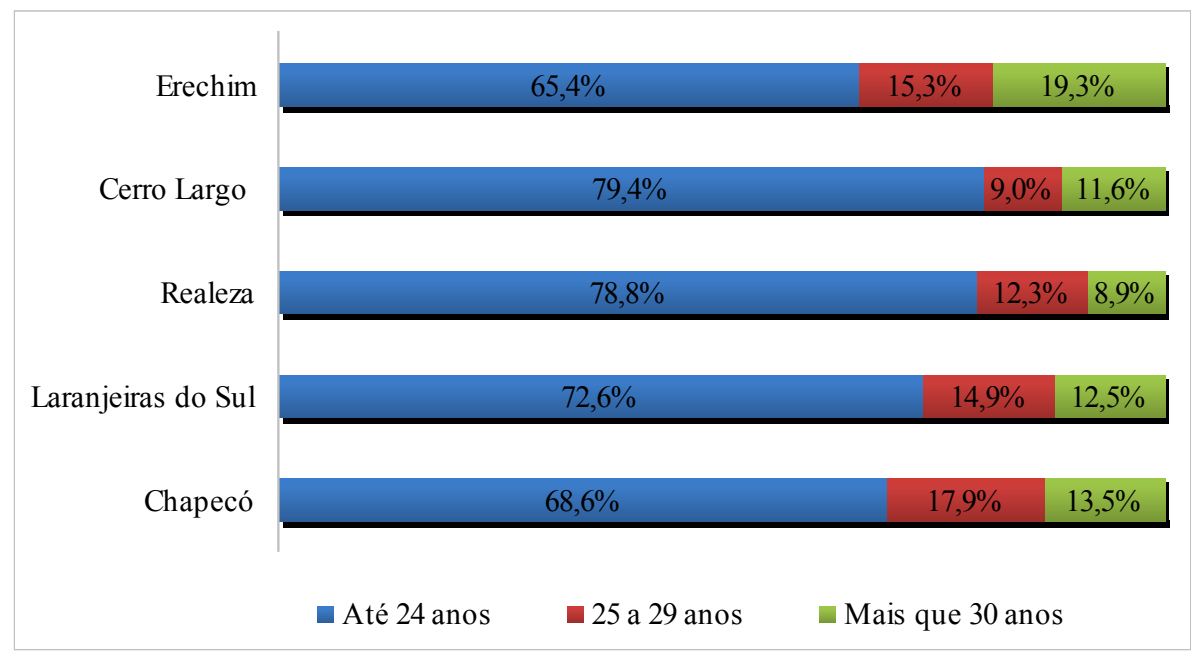

Fonte: Banco de Dados do Processo Seletivo 2012, DRA/PROGRAD/UFFS (elaborado pelos autores).

Ao olhar para os cursos da UFFS e a faixa etária dos ingressantes, observou-se que a predominância é de jovens de até 24 anos, como ilustra o próximo gráfico. $\mathrm{Na}$ faixa etária acima de 24 anos estão presentes principalmente os estudantes em cursos no período noturno, mais especificamente nas licenciaturas. Nos cursos noturnos de Geografia e Ciências Sociais o percentual nessa faixa etária é superior a 50\%. Em cursos como Medicina Veterinária e Nutrição, 90\% ou mais dos ingressantes estão na faixa etária de até 24 anos.

Com relação à faixa etária de 18 a 24 anos, como a idade considerada ideal para o ingresso dos jovens na educação superior, verifica-se que um dos problemas quando isso não acontece é a defasagem idade/série nas etapas anteriores do seu percurso escolar. 


\section{Gráfico 11 - Faixa etária dos ingressantes, por cursos}

Medicina Veterinária - integral

Nutrição - integral

Administração - integral

Arquitetura e Urbanismo - integral

Agronomia - integral

Enfermagem - Integral

Engenharia de Aquicultura - integral

História - matutino

Engenharia Ambiental e Energias Renováveis - integral

Engenharia de Alimentos - integral

Ciência da Computação - matutino

Administração - matutino

Interdisciplinar em Educação no Campo - diurno

Geografia - matutino

Letras - Português e Espanhol - noturno

Ciências: Biologia, Física e Química - noturno

Filosofia - matutino

Pedagogia - noturno

Letras - Português e Espanhol - matutino

Pedagogia - matutino

Administração - noturno

Ciências Sociais - matutino

Ciência da Computação - noturno

História - noturno

Filosofia - noturno

Ciências Econômicas - noturno

Interdiscip linar em Educação no Campo - noturno

Ciências Sociais - noturno

Geografia - noturno
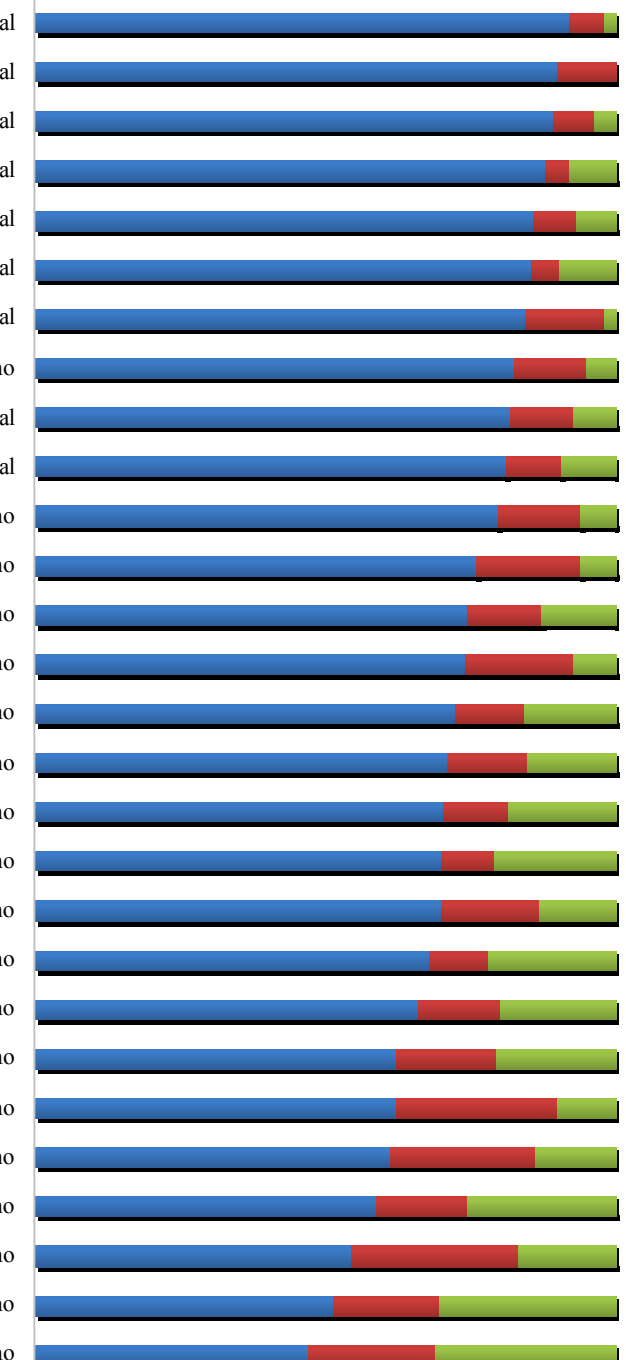

$\begin{array}{lllllllllll}0 \% & 10 \% & 20 \% & 30 \% & 40 \% & 50 \% & 60 \% & 70 \% & 80 \% & 90 \% & 100\end{array}$

—Até 24 anos De 25 a 29 anos Mais que 30 anos $^{\circ}$

Fonte: Banco de Dados do Processo Seletivo 2012, DRA/PROGRAD/UFFS. 
Segundo estudo realizado pelo IBGE (2013a), no ano de 2002, a proporção que frequentava a educação superior, em relação ao total da população na faixa etária de 18 a 24 anos, era de 9,8\%. Em 2012, passou para $15,1 \%$, porém, com a meta prevista para o PNE (2014-2024), esse percentual terá que dobrar para chegar a 33\%. Um dos fatores para que isso aconteça é a diminuição das desigualdades com relação à adequação da idade ao curso frequentado.

Para Ristoff (2013a), para que possa aumentar a taxa de escolarização líquida na educação superior para 33\%, conforme prevê o atual PNE, é fundamental superar a defasagem idade/série existente na educação básica. Para isso, o referido plano apresenta metas abrangentes no sentido de universalizar o ensino fundamental para nove anos a toda a população e elevar a taxa líquida das matrículas do ensino médio para $85 \%$.

Ao observar o período dos últimos 10 anos, essa distorção idade/série, com relação à população de 18 a 24 anos diminuiu, principalmente no ensino fundamental, ou seja, a distorção idade/série está diminuindo. E o ensino médio apresentou uma queda de apenas 3\% nesse período, conforme se verifica no gráfico a seguir. 
Gráfico 12 - Distribuição dos estudantes de 18 a 24 anos de idade, segundo o nível de ensino frequentado ${ }^{6}$ - Brasil - 2002/2012

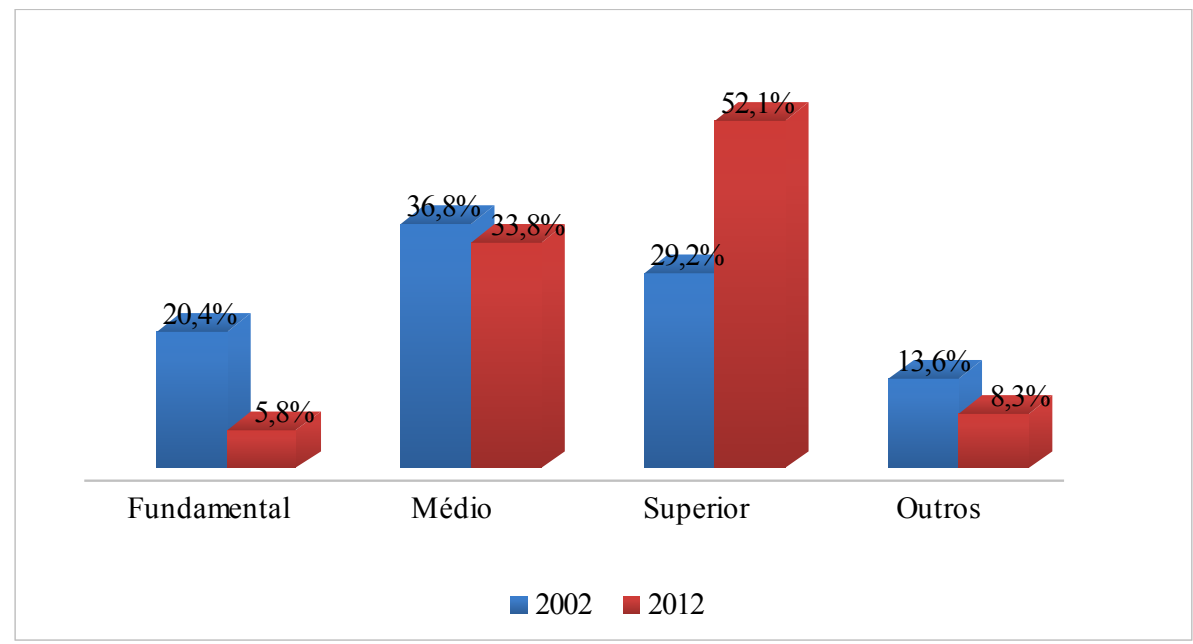

Fonte: IBGE (2013a, p. 125).

Ao verificar os dados do gráfico anterior, constata-se, também, o crescimento da população na faixa etária de 18 a 24 anos na educação superior (incluindo mestrado e doutorado), representado por um percentual de 22,9\%. Porém, muitas diferenças se fazem presentes, principalmente com relação à questão étnico-racial dos estudantes. Conforme IBGE (2013a, p. 125):

[...] essa adequação da idade em relação ao curso frequentado ainda é bastante desigual dependendo da cor ou raça do estudante. Enquanto do total de estudantes brancos de 18 a 24 anos $66,6 \%$ frequentavam o ensino superior, apenas $37,4 \%$ dos jovens estudantes pretos ou pardos cursavam o mesmo nível.

Outra característica, apontada pelo IBGE (2013a), é o percentual de $32,3 \%$ de jovens nessa faixa etária, em 2012, que não haviam concluído o ensino médio e estavam fora da escola. Nos últimos 10 anos houve uma

6 A modalidade "superior" inclui também mestrado e doutorado. A modalidade "outros" representa pré-vestibular, supletivo e alfabetização de adultos. Na contagem do ano de 2002 do IBGE não está incluída a população rural de Rondônia, Acre, Amazonas, Roraima, Pará e Amapá. 
queda de $8 \%$ para essa situação. Essa realidade acontece principalmente com a população considerada mais pobre:

Essa taxa representa o abandono escolar precoce, um importante indicador de vulnerabilidade na medida em que esses jovens podem, futuramente, tornar-se um grupo com menos oportunidades de inserção qualificada no mercado de trabalho. Em 2012, o abandono escolar precoce atingia cerca de metade dos jovens de 18 a 24 anos de idade pertencentes ao quinto mais pobre (53,8\%), enquanto no quinto mais rico essa proporção era de apenas $10,2 \%$ (IBGE, 2013a, p. 126).

Essa reflexão com relação aos demais níveis de ensino, principalmente o ensino médio, é importante quando se analisa a questão do acesso à educação superior. Pois, conforme constatado, a trajetória escolar dos estudantes muitas vezes é interrompida precocemente, antes mesmo de chegar ao ensino superior, principalmente para as camadas mais pobres da sociedade, e acentua-se, ainda mais, quando associada ao aspecto étnico-racial.

\section{Composição étnico-racial dos ingressantes}

A análise dos dados com relação à composição étnico-racial dos ingressantes da UFFS é realizada com base na informação "raça/etnia”. Optou-se, neste estudo, pelo uso das expressões "étnico-raciais" e "etnia/cor", pois, conforme Silva (2014, p. 10),

O termo "raça", devido ao seu processo de construção histórico-social, [...] carrega associações negativas relativas à ideia de hierarquia entre as supostas "raças" humanas. O termo etnia, ao meu ver, é mais aceitável por associar aspectos físicos e culturais (não se restringindo a nenhum deles), portanto seria o mais adequado, no entanto é pouco usado e pouco conhecido pela maioria das pessoas. Uma saída razoável é o uso da expressão étnico-racial, que, 
embora redundante se analisada mais profundamente, evidencia a conjunção de aspectos físicos e culturais.

Ainda, conforme Munanga (2005-2006, p. 53), “o problema fundamental não está na raça, que é uma classificação pseudocientífica rejeitada pelos próprios cientistas da área biológica. O nó do problema está no racismo que hierarquiza, desumaniza e justifica a discriminação existente".

Com base na publicação da Secretaria Especial de Políticas de Promoção da Igualdade Racial (SEPPIR) "Diretrizes Curriculares Nacionais para a Educação das Relações Étnico-Raciais e para o Ensino de História e Cultura Afro-Brasileira e Africana”, a expressão étnico-racial é utilizada no contexto educacional:

[...], o termo raça é utilizado com frequência nas relações sociais brasileiras, para informar como determinadas características físicas, como cor de pele, tipo de cabelo, entre outras, influenciam, interferem e até mesmo determinam o destino e o lugar social dos sujeitos no interior da sociedade brasileira. Contudo, o termo foi ressignificado pelo Movimento Negro que, em várias situações, o utiliza com um sentido político e de valorização do legado deixado pelos africanos. É importante, também, explicar que o emprego do termo étnico, na expressão étnico-racial, serve para marcar que essas relações tensas devidas a diferenças na cor da pele e traços fisionômicos o são também devido à raiz cultural plantada na ancestralidade africana, que difere em visão de mundo, valores e princípios das de origem indígena, europeia e asiática (MEC/SEPIR, 2004, p. 13).

As desigualdades educacionais se fazem presentes no contexto da educação superior, e, conforme já apontada por Feres Júnior et al. (2013), essas desigualdades se acentuam ainda quando se refere às pessoas pretas e pardas. De acordo com o documento do MEC/SEPIR (2004, p. 14), "ainda persiste em nosso país um imaginário étnico-racial que privilegia a brancura e valoriza principalmente as raízes europeias da sua cultura, ignorando ou pouco valorizando as outras, que são a indígena, a africana, a asiática”. 
Na UFFS, ao analisar esse aspecto em relação aos 2.123 ingressantes, em 2012, revelou-se que a maioria é autodeclarada branca. Ainda, $12,0 \%$ dos estudantes se autodeclaram pardos; $1,7 \%$, pretos, $0,8 \%$, amarelos e $0,0 \%$, indígenas. Além disso, $0,6 \%$ dos estudantes não responderam $^{7}$. O percentual de indígenas aparece como $0,0 \%$, por se tratar de apenas um estudante.

O gráfico 13 apresenta o percentual de estudantes, conforme sua autodeclaração étnico-racial, nos cinco campi da UFFS. Percebe-se que há uma pequena diferença entre os campi. A população de estudantes autodeclarada branca é maior no Estado do Rio Grande do Sul. Nos campi do estado do Paraná, o grupo de estudantes autodeclarados pretos, pardos, indígenas e amarelos é ligeiramente maior em relação aos demais campi. Os autodeclarados amarelos estão presentes mais no Estado do Paraná e Santa Catarina.

Gráfico 13 - Composição étnico-racial dos estudantes da UFFS, por campus

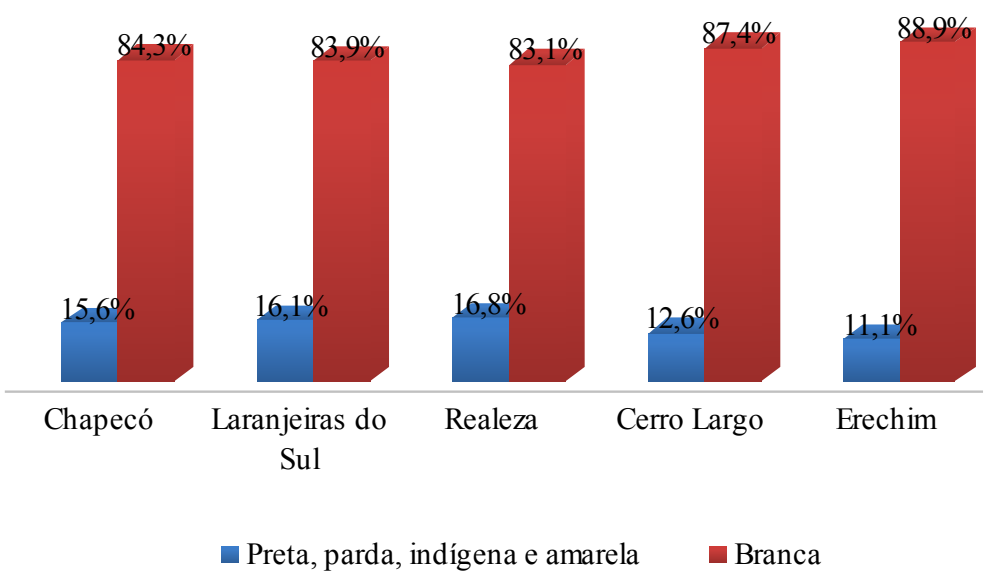

Fonte: Banco de Dados do Processo Seletivo 2012, DRA/PROGRAD/UFFS.

7 Para a apresentação gráfica dos dados foi desconsiderado a variável "não declarado", sendo recalculados os valores. As variáveis foram agrupadas em apenas duas: "branca" e "preta, parda, indígena e amarela". Para os dados do MEC/ INEP (2014a), apresentados mais adiante, também foram desconsideradas as variáveis "não dispõe da informação" e "não declarado", sendo recalculados os valores agrupando-os também nas duas variáveis, já mencionadas. 
A pesquisa da Andifes/Fonaprace $(2011)^{8}$ revela que a maioria dos estudantes de graduação das universidades federais em 2010, se autodeclarou branca, representada por 53,9\%. Em comparação com o mesmo tipo de pesquisa realizado em 2004, os dados mostraram que nesse período houve um aumento da etnia/cor preta de 5,9\% para 8,7\%. Destaca que esse aumento também ocorreu nas demais regiões, principalmente nas regiões Norte e Nordeste. A pesquisa aponta que essa configuração pode ser entendida pelas políticas inclusivas adotadas nas universidades federais por meio de modalidades de ações afirmativas e pelos programas de expansão dessas universidades. Para a Região Sul, a pesquisa da Andifes/Fonaprace (2011) apresentou um percentual de 84,64\% estudantes autodeclarados brancos.

Ao comparar os dados relacionados à característica étnico-racial da população brasileira com as matrículas realizadas nas IES, constata-se que os estudantes que acessam o ensino superior ainda não representam na sua totalidade os dados da realidade. $\mathrm{Na}$ Região Sul, observou-se que os dados das IES se aproximam dos da população, com predominância para a população autodeclarada branca.

Com referência às características étnico-raciais, o gráfico 14 ilustra uma perspectiva comparativa entre os ingressantes na UFFS, as matrículas nas demais IES e a população brasileira, no âmbito nacional e regional. 
Gráfico 14 - Composição étnico-racial da população e das IES da Região Sul e da UFFS

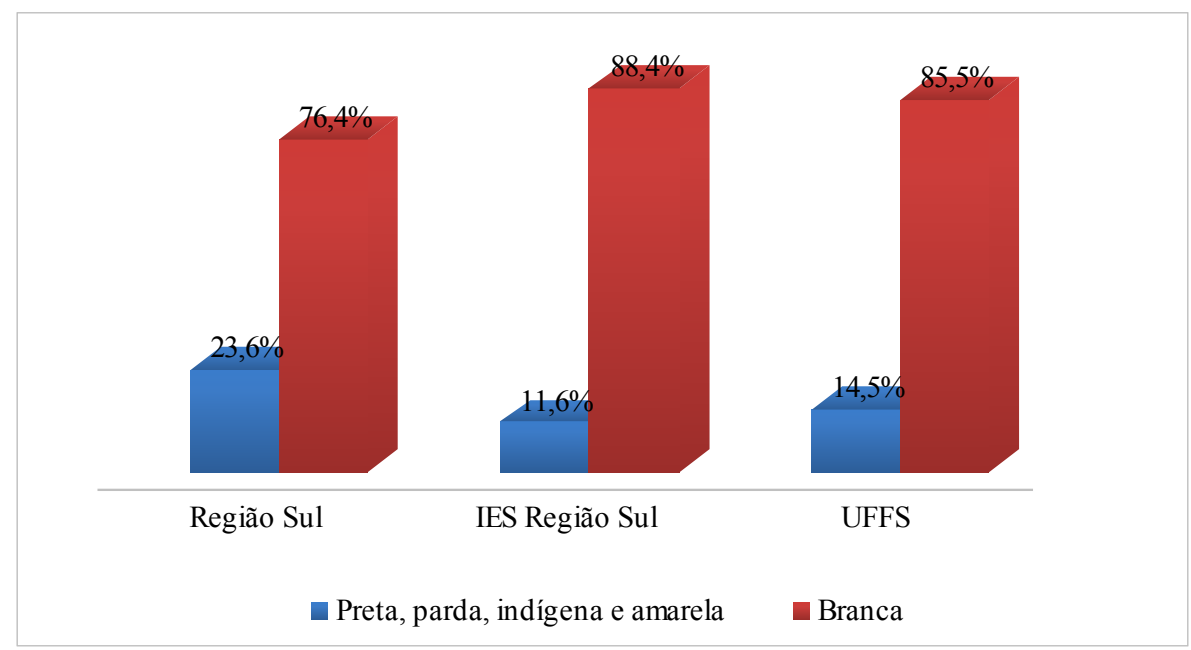

Fonte: Banco de Dados do Processo Seletivo 2012, DRA/PROGRAD/UFFS; IBGE (2014); MEC/INEP ${ }^{9}$ (2014a).

O Censo Demográfico $2010^{10}$ constatou que, em termos de "cor ou raça”, a população brasileira, nos últimos dez anos, modificou seu perfil. "Destaca-se uma menor proporção de pessoas que se declaram brancas e uma maior proporção das pessoas que se declaram como pretas ou pardas. Esse conjunto passou de 44,7\% da população; em 2000; para 50,7\%, em 2010" (IBGE, 2011, p. 46). A valorização da identidade afrodescendente pode ser considerada uma possível explicação para tal dinâmica. Também chama atenção o fato de que no Censo de 2010 todas as pessoas se autodeclararam, como explicita o próximo gráfico, de acordo com os períodos mencionados.

Os dados da PNAD 2012 revelaram que, no contingente da população brasileira, $46,3 \%$ se autodeclara branca, $7,9 \%$ preta, $0,5 \%$ amarela, $45 \%$ parda e $0,3 \%$ indígena. Os autodeclarados pardos configuram a segunda categoria

\footnotetext{
9 O INEP utiliza cor/raça.

10 O IBGE utiliza as expressões cor ou raça.
} 
mais numerosa, e, ao ser somada com a população autodeclarada preta, o percentual ultrapassa o da população autodeclarada branca (IBGE, 2014).

Gráfico 15 - Percentual da população residente, segundo a "cor ou raça" no Brasil $-2000 / 2010$

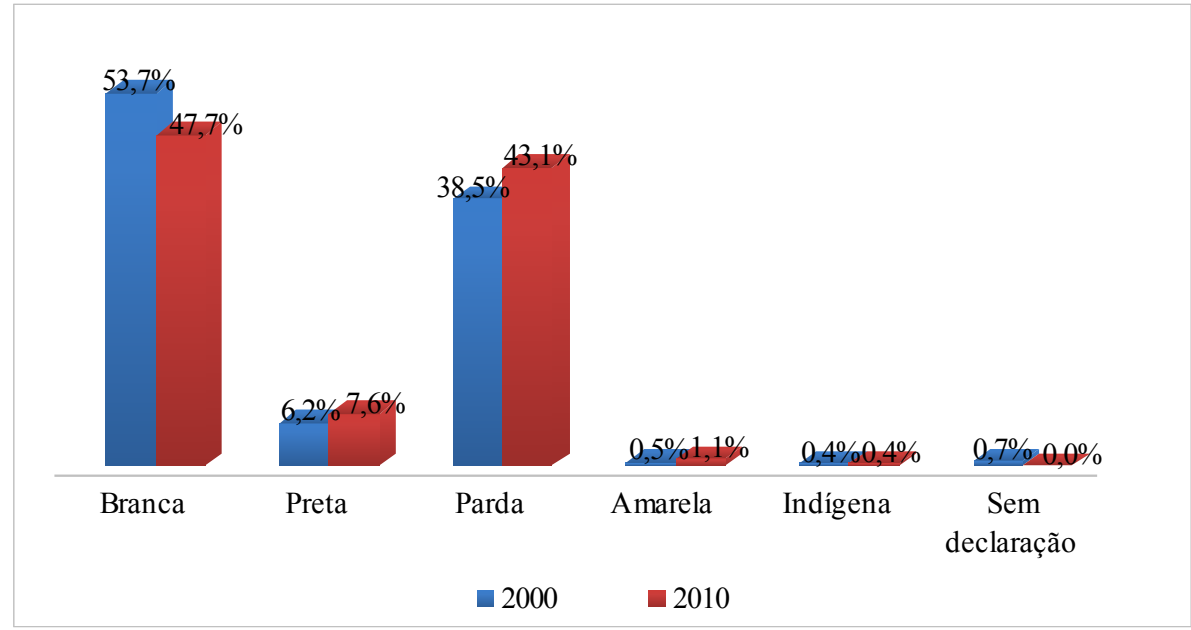

Fonte: IBGE (2011, p. 47).

Na Região Sul, a composição étnico-racial difere das demais regiões e se aproxima da Região Sudeste, pois, conforme se observa no gráfico a seguir, apresenta uma expressiva população autodeclarada branca, representada por $76,8 \%$. 
Gráfico 16 - Composição étnico-racial da população brasileira, por regiões

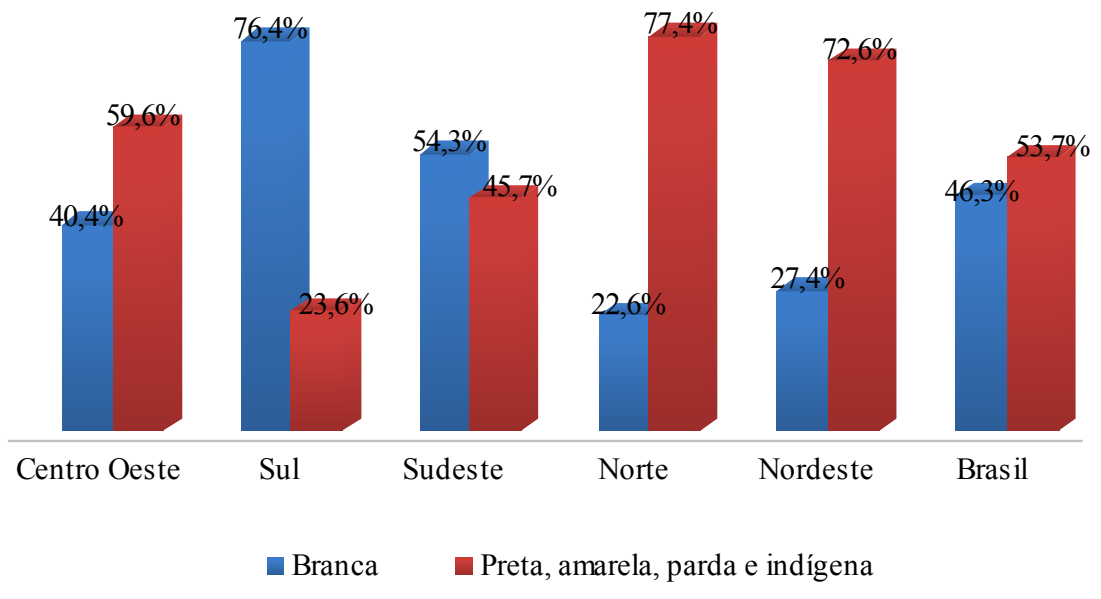

Fonte: PNAD 2012 (IBGE, 2014).

Com relação às desigualdades educacionais, com base nas relações étnico-raciais, dados apresentados pelo MEC/INEP (2014a) demonstram que a população classificada como branca e amarela possui uma média maior de anos de estudo em relação à população classificada como preta, parda e indígena. Porém, ao sinalizar os dados no período de 2005 a 2012 (tabela 2), constata que houve um crescimento visível para pretos e pardos.

Tabela 2 - Média de anos de estudo da população com idade acima de 18 anos, por cor/raça - Brasil - 2005-2012

\begin{tabular}{l|l|l|l|l|l|l}
\hline \multirow{2}{*}{ Ano } & \multirow{2}{*}{ Brasil } & \multicolumn{6}{l}{ Cor/Raça } & \multicolumn{5}{l}{} \\
\cline { 3 - 7 } & & Branco & Preto & Pardo & Amarelo (1) & Indígena (1) \\
\hline 2005 & 7,0 & 7,8 & 6,2 & 5,9 & 10,1 & 5,9 \\
\hline 2006 & 7,2 & 8,1 & 6,3 & 6,1 & 10,0 & 6,5 \\
\hline 2007 & 7,3 & 8,2 & 6,4 & 6,3 & 9,0 & 6,4 \\
\hline 2008 & 7,4 & 8,3 & 6,6 & 6,5 & 9,4 & 6,4 \\
\hline 2009 & 7,6 & 8,4 & 6,7 & 6,6 & 10,1 & 6,4 \\
\hline $2010(2)$ &.. &.. &.. &.. &.. &.. \\
\hline 2011 & 7,7 & 8,6 & 6,8 & 6,9 & 9,6 & 6,3 \\
\hline 2012 & 7,9 & 8,8 & 7,1 & 7,1 & 10,2 & 6,6 \\
\hline
\end{tabular}

Fonte: MEC/INEP (2014a, p. 43). 
Notas: (1) "Essas duas populações terão grande variação pela baixa representatividade amostral".

(2) Como no ano de 2010 é realizado o Censo Demográfico, não se dispõe, nesse ano, dos dados da PNAD" (MEC/INEP, 2014a, p. 43).

\section{Questão étnico-racial como um desafio à educação superior}

Os estudos realizados sobre essa temática apontam que a democratização do acesso das pessoas pretas, pardas e indígenas à educação superior apresentou avanços nas últimas décadas, porém, ainda é um desafio a ser vencido.

Um estudo realizado em 2013, sobre o impacto da Lei $\mathrm{n}^{\circ}$ 12.711/2012 no seu primeiro ano de funcionamento, apontou que houve um aumento no percentual de vagas oferecidas em todas as regiões para pretos, pardos e indígenas, já que a lei estabelece um mínimo para cada Estado. Segundo a pesquisa, no que diz respeito às cotas étnico-raciais, os percentuais se revelaram positivos, pois contemplou a lei e até ultrapassou o percentual previsto. Observou-se que, no ano de 2012, a população de índios, pretos e pardos, da Região Sul, era de 20,9\%, e as universidades ofertavam em torno de 10,1\% das vagas. A partir da nova legislação, em 2013 passaram a ofertar um percentual de 17,7\% (FERES JÚNIOR et al., 2013).

Na UFFS, esses números também podem ser observados, pois a modalidade de ação afirmativa adotada nos três primeiros anos (2010-2012) tinha apenas o critério de escola pública e não contemplava o quesito étnico-racial. A partir da aplicação da lei, no ano de 2013, com base em dados complementares fornecidos pela Diretoria de Registro Acadêmico da UFFS, percebeu-se que houve um crescimento de estudantes autodeclarados pretos e indígenas e, principalmente, de pardos.

Ao analisar o período de 2010 a 2014, considerando todas as formas de ingresso na UFFS ${ }^{11}$, constatou-se que nos anos de 2013 e 2014 ocorreu

11 ENEM; processo seletivo especial; processo seletivo especial (PROHAITI); retorno de aluno abandono; retorno de graduado; transferência ex-offício; transferência externa e transferência interna. Os dados foram gerados e disponibilizados pela Diretoria de Registro Acadêmico. 
um aumento de estudantes autodeclarados pardos, pretos e indígenas, principalmente por meio de processos seletivos especiais, como é o caso dos cursos, com regime de alternância nos campi Laranjeiras do Sul e Erechim e o Programa PROHAITI, no Campus Chapecó. Observou-se, também, que, ao longo desse período, os percentuais de estudantes autodeclarados indígenas se mantiveram baixos. Essa realidade poderá ser modificada a partir dos processos seletivos especiais destinados aos povos indígenas.

A tabela 3 demonstra a condição étnico-racial dos ingressantes de todos os campi da UFFS, no período entre 2010 a 2014, considerando todas as formas de ingresso.

Tabela 3 - Composição étnico-racial dos estudantes da UFFS (2010-2014)

\begin{tabular}{|c|c|c|c|c|c|}
\hline \multirow[t]{2}{*}{ Etnia/cor } & \multicolumn{5}{|l|}{ Ano } \\
\hline & 2010 & 2011 & 2012 & 2013 & 2014 \\
\hline Amarela & 0,9 & 0,9 & 0,9 & 0,8 & 0,8 \\
\hline Branca & 82,7 & 80,8 & 81,5 & 78,3 & 74,4 \\
\hline Indígena & 0,1 & 0,1 & 0 & 0,9 & 1,9 \\
\hline Não declarada & 2,9 & 4,8 & 5,7 & 0,9 & 4,1 \\
\hline Parda & 11,8 & 11,7 & 10,2 & 16,7 & 14,9 \\
\hline Preta & 1,6 & 1,7 & 1,7 & 2,4 & 3,8 \\
\hline
\end{tabular}

Fonte: Sistema de Gestão Acadêmica (SGA) / Diretoria de Registro Acadêmico/UFFS, 2014.

Constatou-se que os percentuais se aproximam ainda mais da realidade populacional da Região Sul, pois, somada, a população autodeclarada amarela, preta, parda e indígena corresponde a 23,6\% (IBGE, 2014). Na UFFS, em 2014, o percentual de estudantes com essa composição étnico-racial foi de $21,4 \%$.

Com o objetivo de demonstrar um caso concreto de implementação da "Lei das Cotas", em universidades federais da Região Sul, a partir de sua aprovação, a tabela 4 apresenta um levantamento dessa informação, a partir de consulta ao Mapa das Ações Afirmativas, realizado pelo Grupo de Estudos Multidisciplinares da Ação Afirmativa (GEMAA) da Universidade Estadual do Rio de Janeiro (UERJ). 
Tabela 4 - Implantação da Lei 12.711 nas IES públicas federais na Região Sul ${ }^{12}$, em 2013

\begin{tabular}{l|l|l}
\hline IES & Beneficiários & Total de vagas reservadas \\
\hline UFCSPA (RS) & $\begin{array}{l}\text { Escola pública, baixa renda, pretos e pardos } \\
\text { e indígenas }\end{array}$ & $12,50 \%$ \\
\hline UNIPAMPA (RS) & $\begin{array}{l}\text { Escola pública, baixa renda, pretos e pardos, } \\
\text { indígenas e deficientes }\end{array}$ & $50,00 \%$ \\
\hline UFSM (RS) & $\begin{array}{l}\text { Escola pública, baixa renda, pretos e pardos, } \\
\text { indígenas e deficientes }\end{array}$ & $61,80 \%$ \\
\hline FURG (RS) & $\begin{array}{l}\text { Escola pública, baixa renda, pretos e pardos, } \\
\text { indígenas e quilombolas }\end{array}$ & $30,80 \%$ \\
\hline UFRGS (RS) & $\begin{array}{l}\text { Escola pública, baixa renda, pretos e pardos } \\
\text { e indígenas }\end{array}$ & $31,00 \%$ \\
\hline UFFS (SC/PR/RS) & $\begin{array}{l}\text { Escola pública, baixa renda, pretos e pardos } \\
\text { e indígenas }\end{array}$ & $89,90 \%$ \\
\hline UFSC (SC) & $\begin{array}{l}\text { Escola pública, baixa renda, pretos e pardos } \\
\text { e indígenas }\end{array}$ & $43,00 \%$ \\
\hline UNILA (PR) & $\begin{array}{l}\text { Escola pública, baixa renda, pretos e pardos } \\
\text { e indígenas }\end{array}$ & $50,00 \%$ \\
\hline UFPR & $\begin{array}{l}\text { Escola pública, baixa renda, pretos e pardos } \\
\text { e indígenas }\end{array}$ & $40,30 \%$ \\
\hline UTFPR & $\begin{array}{l}\text { Escola pública, baixa renda, pretos e pardos } \\
\text { e indígenas }\end{array}$ & $52,90 \%$ \\
\hline
\end{tabular}

Fonte: Mapa das Ações Afirmativas no Brasil (GEMAA, 2015).

Percebeu-se, pela análise dos percentuais apresentados na tabela anterior, que, após a aprovação da Lei no $12.711 / 2012$, no seu primeiro processo seletivo, metade das universidades federais da Região Sul, consideradas no respectivo Mapa das Ações Afirmativas, aderiu à reserva de $50 \%$ ou mais de suas vagas, conforme os critérios da respectiva lei. Observou-se que existem reservas de vagas destinadas também para quilombolas e deficientes. A UFFS se destaca, dentre as demais IES, com o maior percentual de reserva de vagas. 


\section{Condições de moradia}

No desenvolvimento da pesquisa, procurou-se levantar dados sobre as condições de moradia dos ingressantes na UFFS. No que se refere ao número de pessoas que residiam com os estudantes, no momento em que realizaram a sua inscrição na Instituição, $61,3 \%$ indicaram que era entre uma e três pessoas, conforme demonstra o gráfico 17. Constata-se que, em sua maioria, os estudantes residiam com seus familiares.

Gráfico 17 - Número médio de pessoas que moram na residência dos estudantes

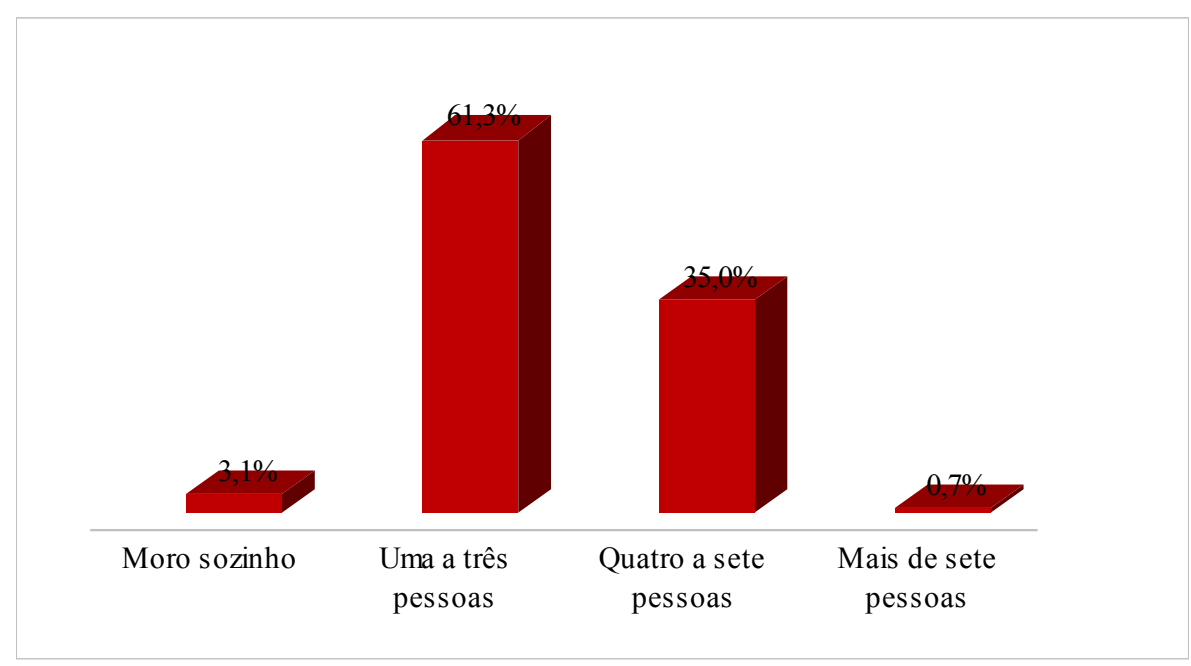

Fonte: Banco de Dados do Processo Seletivo 2012, DRA/PROGRAD/UFFS.

Na UFFS, a maioria dos ingressantes informou que a situação de moradia é a casa própria (66,9\%). Essa situação, muitas vezes se altera, tendo em vista o início do curso de graduação, principalmente para aqueles que residem distantes da universidade e precisam sair da casa dos seus familiares para estudar, passando a residir na cidade do campus ou em cidades mais próximas.

Com relação à localização da moradia, 73,2\% dos estudantes da UFFS residiam na zona urbana e, $26,8 \%$, na zona rural. Cumpre destacar que, embora não apareça nos percentuais, um estudante declarou a "comunidade 
quilombola", como local de moradia. O percentual de ingressantes residentes no meio rural está acima da média nacional, conforme demonstra o gráfico 18.

No Brasil há uma nítida tendência à urbanização, cujo processo se acentuou nas últimas décadas. O censo demográfico do IBGE (2011, p. 31 ), com referência ao ano de 2010, observa que:

A concentração da população que reside em áreas urbanas é um fenômeno crescente no País. A proporção de pessoas nestas áreas passou de $45,1 \%$, em 1950, para 84,4\%, em 2010. Em relação a 2000, quando o grau de urbanização era de $81,2 \%$, o ritmo de crescimento da população em áreas urbanas desacelera.

Gráfico 18 - Localização da moradia no Brasil, Região Sul e UFFS, em 2012

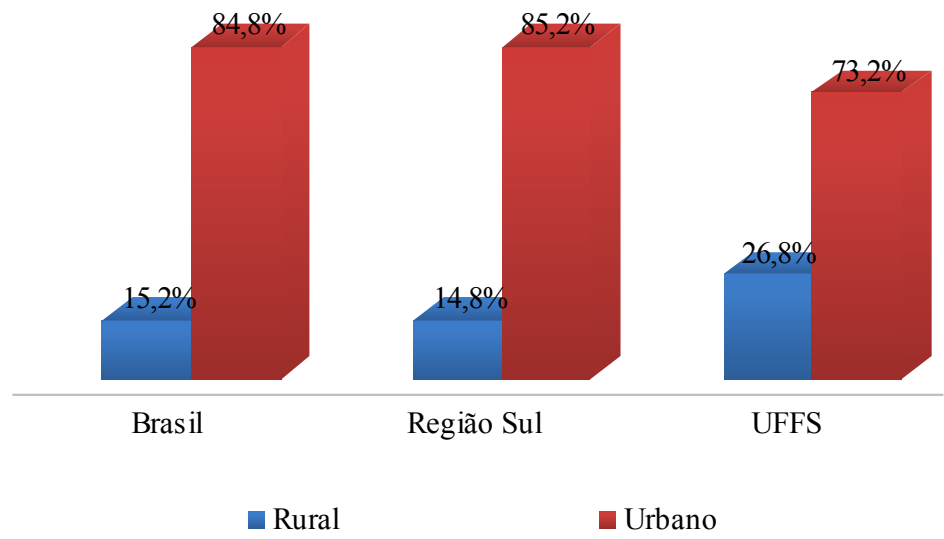

Fonte: Banco de Dados do Processo Seletivo 2012, DRA/PROGRAD/UFFS e IBGE (2014).

Procurou-se saber, também, os percentuais de estudantes urbanos e rurais em cada um dos campi da UFFS, apresentados no gráfico 19, no qual se verifica o Campus Cerro Largo com o maior percentual de estudantes residentes no campo. 
Gráfico 19 - Localização da moradia dos estudantes da UFFS, por campus

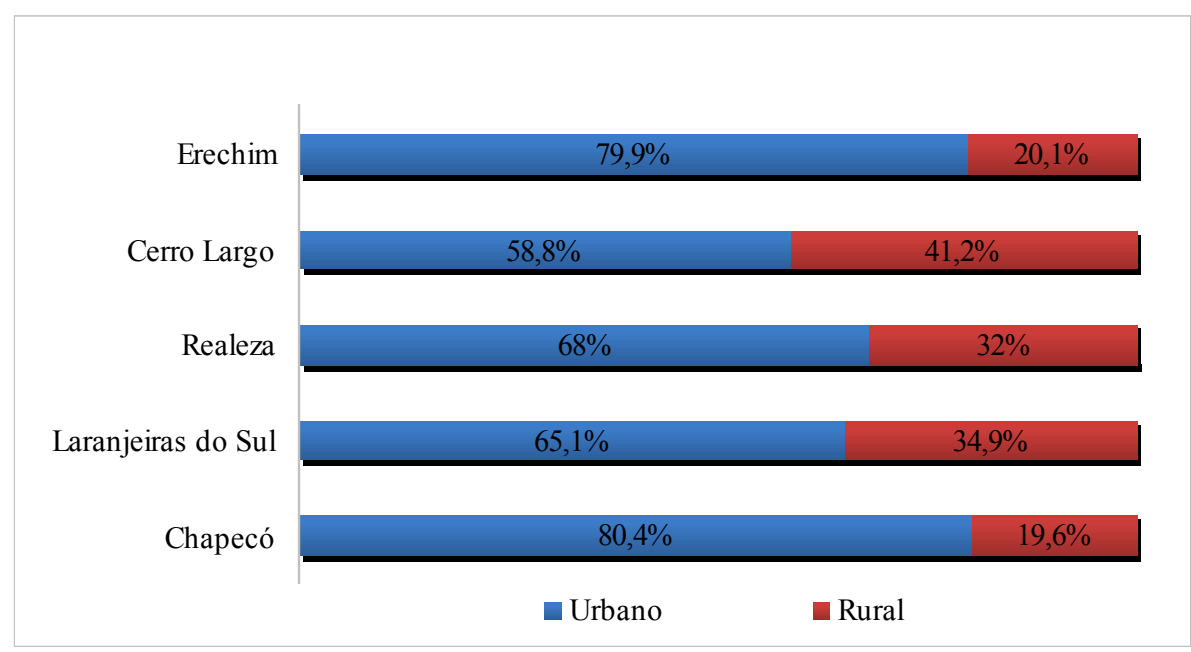

Fonte: Banco de Dados do Processo Seletivo 2012, DRA/PROGRAD/UFFS.

\section{Trabalho e renda familiar dos ingressantes}

\section{Trabalho}

O trabalho é, notadamente, uma dimensão estruturante da vida em sociedade. Como dizia Marx (1996), o trabalho é uma relação entre o homem e a natureza. Para o autor,

O processo de trabalho [...] é atividade orientada a um fim para produzir valores de uso, apropriação do natural para satisfazer as necessidades humanas, condição universal do metabolismo entre o homem e a Natureza, condição natural eterna da vida humana e, portanto, independente de qualquer forma dessa vida, sendo antes igualmente comum a todas as suas formas sociais (MARX, 1996, p. 303).

Tendo isso presente, buscou-se conhecer como essa dimensão se apresenta na vida dos ingressantes da UFFS, em 2012. 
A pesquisa demonstrou que $71,1 \%$ dos estudantes já haviam exercido alguma atividade que eles próprios consideravam trabalho. No momento da sua inscrição no Processo Seletivo da UFFS, mais da metade dos estudantes informou trabalhar ${ }^{13}$, tanto em vínculos formais, quanto informais. Entre os estudantes do sexo masculino e feminino, observou-se que entre os homens, $65,4 \%$ informou trabalhar e entre o total das mulheres, $55,9 \%$.

O gráfico 20 revela que os estudantes da UFFS são trabalhadores, ou seja, mais de $40 \%$ recorrem ao mundo do trabalho em busca de recursos para o pagamento de suas despesas.

Gráfico 20 - Vínculo empregatício dos estudantes da UFFS, em 2012

Trabalho em tempo parcial sem remuneração

Outro (tarefas domésticas, freelance, etc.)

Trabalho em tempo parcial remunerado

Não trabalho, mas procuro por um trabalho

Não trabalho
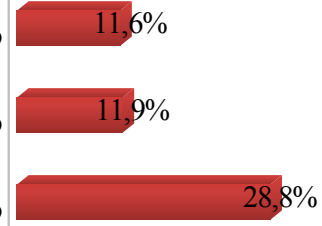

Trabalho em tempo integral remunerado

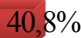

Fonte: Banco de Dados do Processo Seletivo 2012, DRA/PROGRAD/UFFS.

O próximo gráfico mostra que o Campus Chapecó apresenta o maior percentual de estudantes que trabalhavam ${ }^{14}$.

13 Para a formação deste percentual foram excluídas apenas as seguintes variáveis: "não trabalho" e "não trabalho, mas procuro por um trabalho".

14 Para este gráfico as variáveis foram juntadas em apenas duas: "trabalha" e "não trabalha". Na primeira incluem-se: "trabalho em tempo parcial remunerado", "outro (por ex.: tarefas domésticas, trabalha aos fins de semana - freelance, etc.)"; "trabalho em tempo integral remunerado" e "trabalho em tempo parcial sem remuneração". Na segunda incluem-se: "não trabalho, mas procuro por um trabalho" e "não trabalho". 
Gráfico 21 - Vínculo empregatício dos estudantes da UFFS, em 2012, por campus

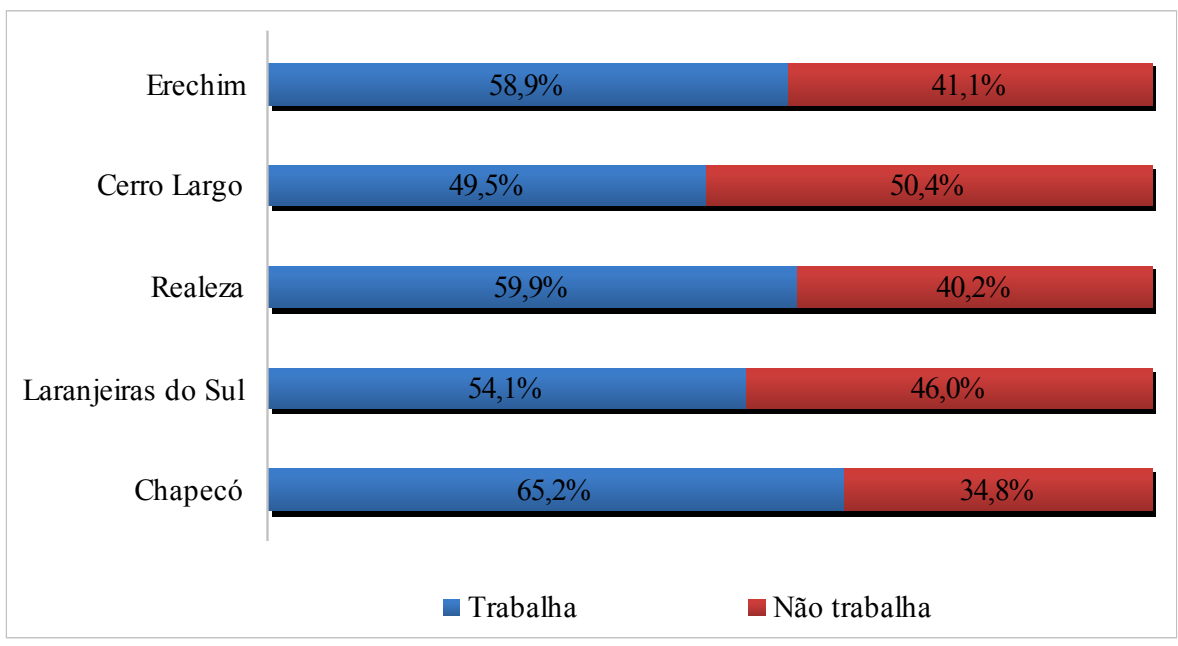

Fonte: Banco de Dados do Processo Seletivo 2012, DRA/PROGRAD/UFFS.

A pesquisa de Pereira (2014), no que tange ao perfil dos ingressantes da UFFS, no Campus Erechim, no ano de 2012, aponta que entre os estudantes trabalhadores, as ocupações mais frequentes foram nas áreas do comércio e de serviços. Atividades como garçons, secretárias, vendedores, empacotadores, atendentes são as mais comuns, principalmente pela característica econômica da região de entorno de Erechim. Também aparecem as ocupações ligadas ao serviço público e às atividades do setor primário.

Observa-se no gráfico a seguir que há uma relação de trabalho maior principalmente nos cursos de licenciaturas e/ou cursos ofertados no período noturno. 


\section{Gráfico 22 - Vínculo empregatício dos estudantes da UFFS, em 2012, por curso}

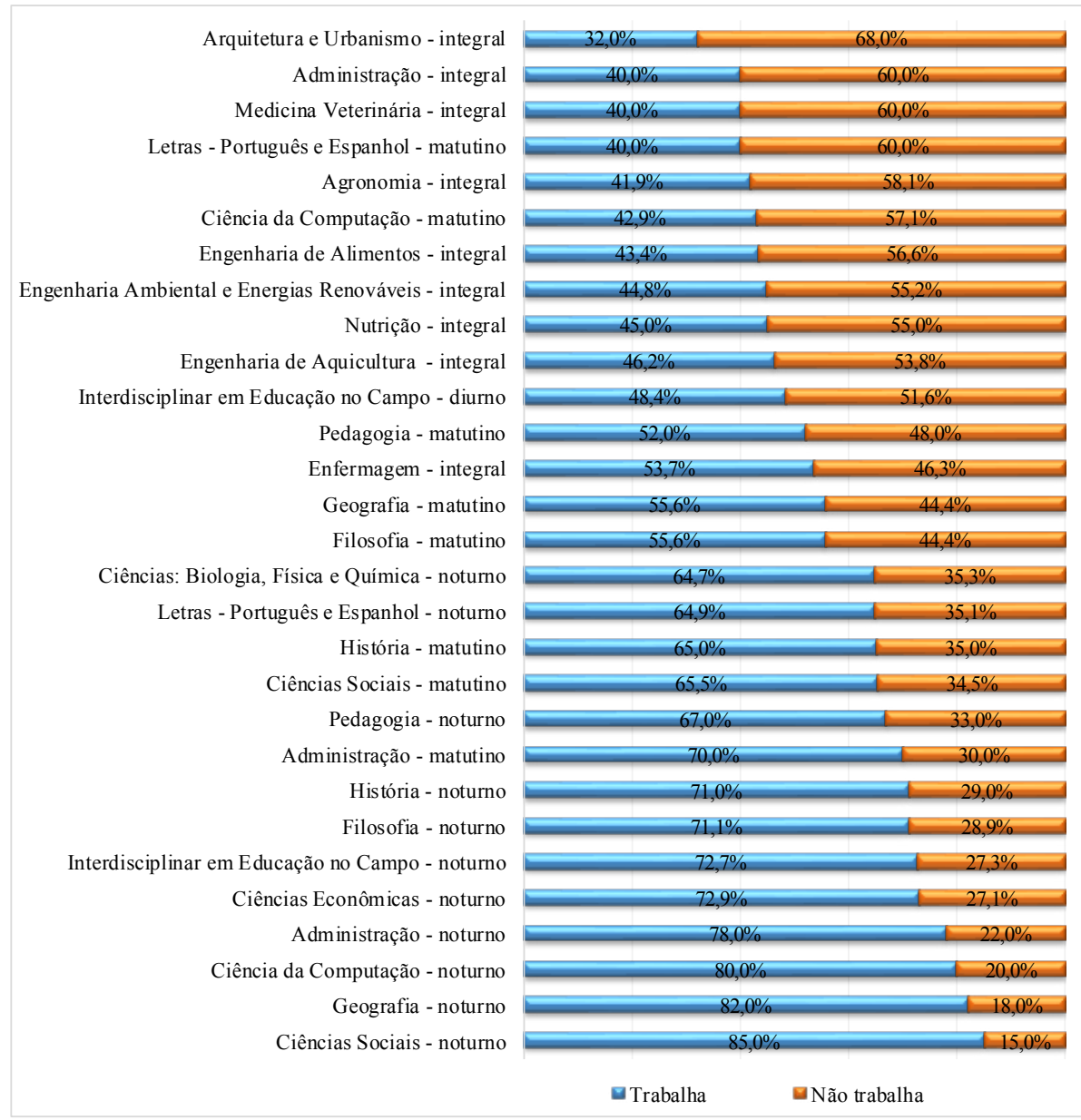

Fonte: Banco de Dados do Processo Seletivo 2012, DRA/PROGRAD/UFFS.

Indagados sobre as razões que os levaram a trabalhar ${ }^{15}$, a maioria atribuiu maior importância à necessidade de sustentar a si mesmo e adquirir experiência.

15 Nessa questão houve uma reorganização das respostas. Elas foram identificadas, em cada frase, pelas expressões "pouco" e "muito", ou seja, para a primeira foi juntado os graus de importância representados pelos números 0, 1 e 2. Para a segunda foi juntado os números 3, 4 e 5. 
Gráfico 23 - Grau de importância na decisão de trabalhar dos estudantes

Sustentar sua família (esposo (a), filhos (as), etc.).

Para ajudar os pais nas despesas coma casa

Para custear / pagar seus estudos

Para adquirir experiência

Para ser independente (ganhar meu próprio dinheiro)

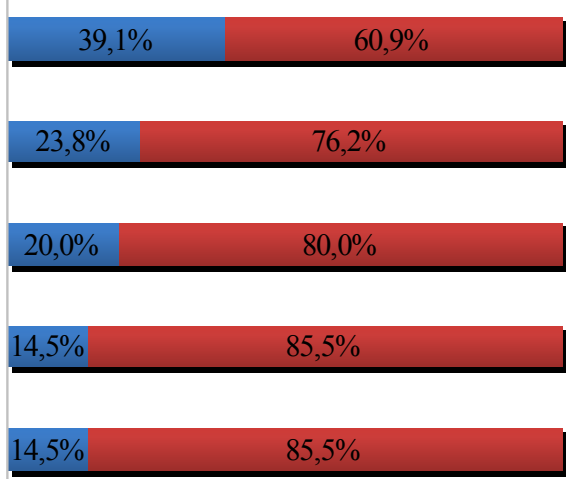

Pouco

Muito

Fonte: Banco de Dados do Processo Seletivo 2012, DRA/PROGRAD/UFFS.

Procurou-se descobrir, também, a carga horária média de trabalho, e, $28,3 \%$ responderam que trabalhavam mais de 40 horas semanais.

Gráfico 24 - Quantidade média de horas trabalhadas, por semana

Sem jornada fixa, até 10 horas semanais

De 21 a 30 horas semanais

De 11 a 20 horas semanais

De 31 a 40 horas semanais

Mais de 40 horas semanais

Não se aplica
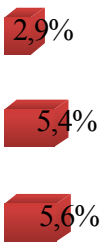

$16,0 \%$
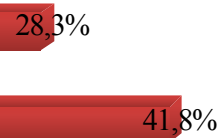

Fonte: Banco de Dados do Processo Seletivo 2012, DRA/PROGRAD/UFFS. 
Ao referir-se à idade dos estudantes ao ingressarem no mercado de trabalho, nota-se que ocorreu, em média, antes dos 14 anos.

Gráfico 25 - Percentual referente à idade de ingresso dos estudantes no mercado de trabalho

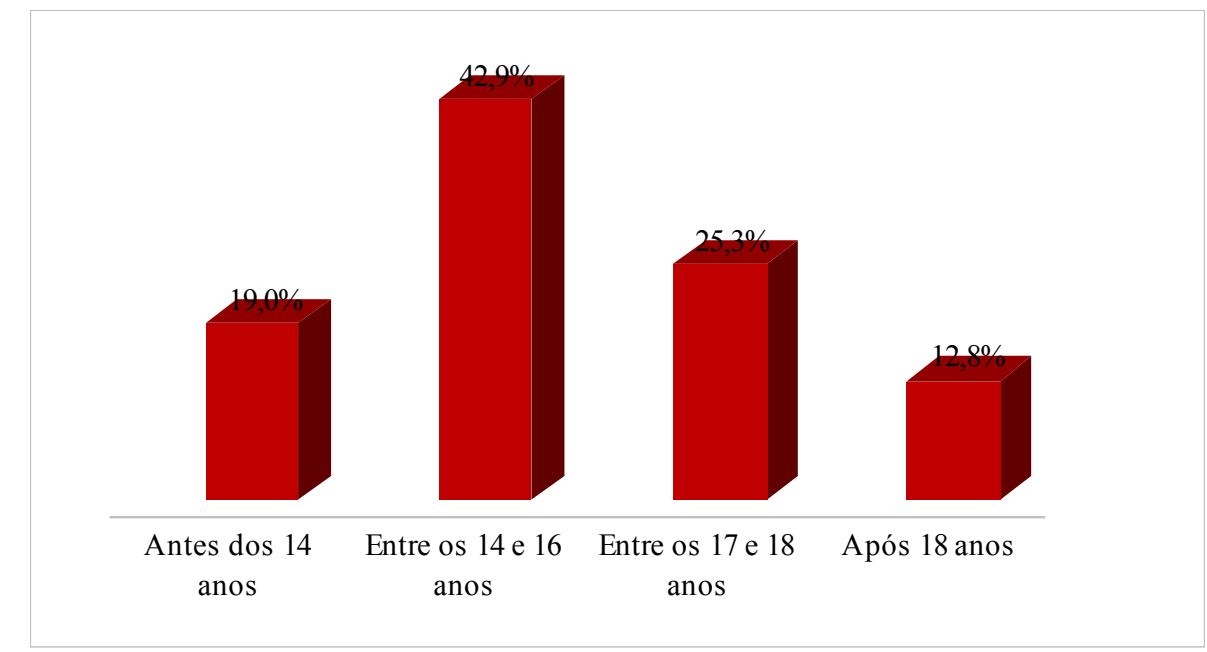

Fonte: Banco de Dados do Processo Seletivo 2012, DRA/PROGRAD/UFFS.

O gráfico 26 mostra os dados em nível nacional e da Região Sul, com base na PNAD 2012, que considerou os trabalhadores ativos, a partir de 10 anos ou mais de idade. É possível perceber que a maioria dos trabalhadores brasileiros ingressa no mercado de trabalho antes dos 18 anos. Desses, um percentual significativo aponta ter iniciado a vida laborativa antes mesmo dos 14 anos de idade. Na Região Sul, os jovens ingressam mais cedo, ao comparar com os dados em nível nacional (IBGE, 2014). 
Gráfico 26 - Idade média de ingresso da população do Brasil e da Região Sul no mercado de trabalho

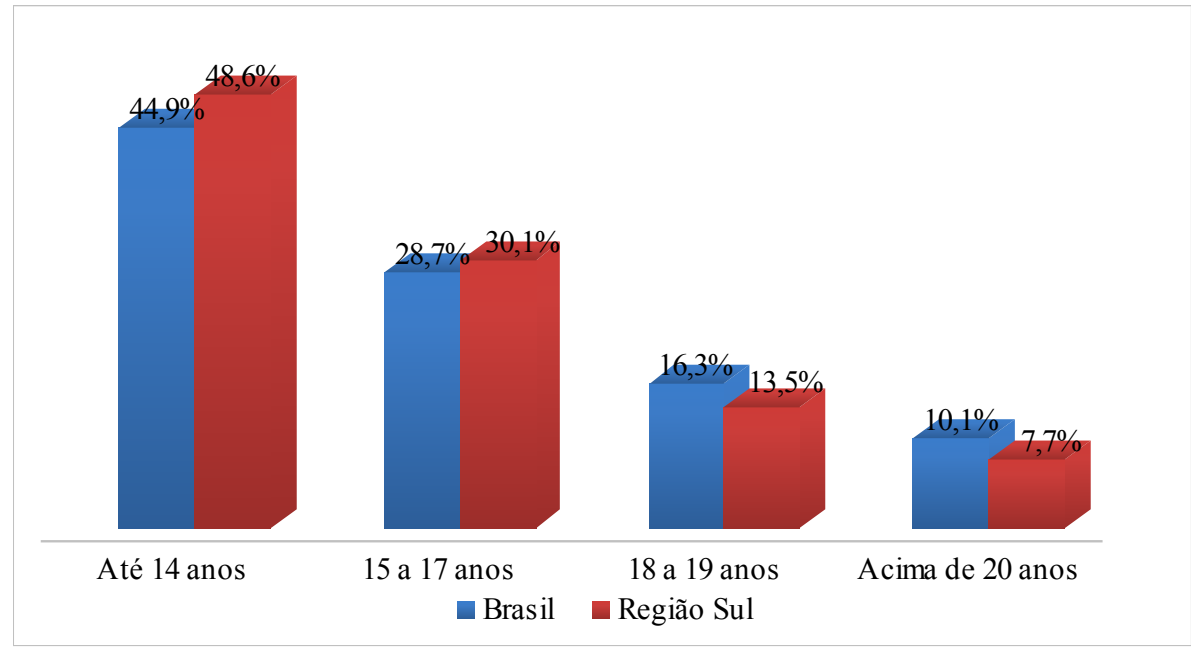

Fonte: IBGE (2014).

Quanto ao sexo dos estudantes da UFFS em relação à condição de trabalho, observou-se que, em ambos os sexos, trabalha. Contudo, há uma incidência maior entre estudantes do sexo masculino.

Gráfico 27 - Condição de trabalho na UFFS, por sexo

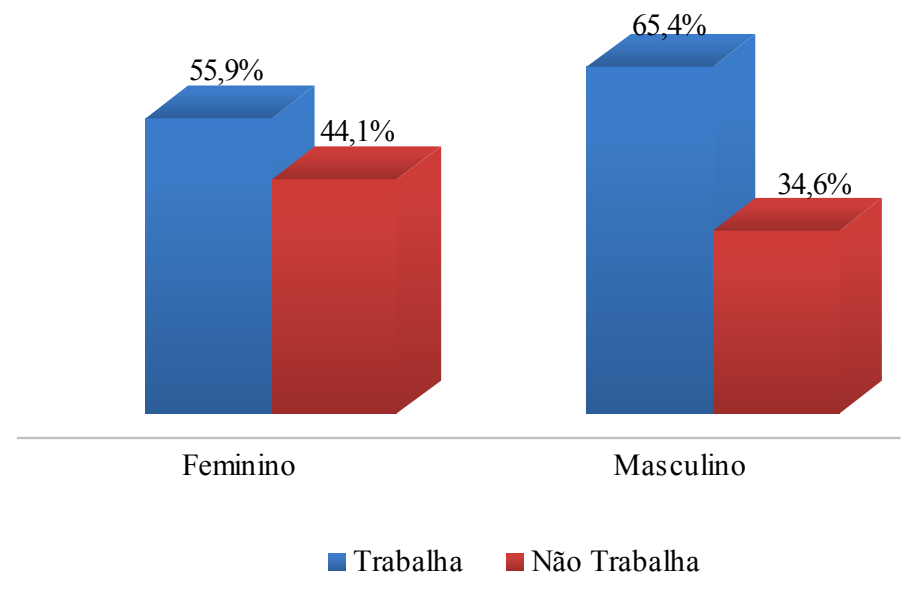

Fonte: Banco de Dados do Processo Seletivo 2012, DRA/PROGRAD/UFFS. 
Segundo o IBGE (2014), a presença masculina é maior no mercado de trabalho, ainda que a participação feminina tenha se elevado nas últimas décadas.

Com relação à situação de trabalho dos estudantes universitários, em nível nacional, com base nos dados da Andifes/Fonaprace (2011), 37,63\% dos estudantes informaram trabalhar no momento da pesquisa. Nas IES da Região Sul, 46,3\% dos estudantes indicou o envolvimento com trabalho.

Um estudo sobre o perfil dos estudantes universitários, com base nos dados do Questionário Socioeconômico do Exame Nacional de Desempenho de Estudantes (ENADE) do segundo ciclo (2007, 2008 e 2009), revelou que "aproximadamente $44 \%$ dos estudantes não trabalham e têm seus gastos financiados pela família. Isto significa que 56\% dos estudantes brasileiros trabalham e estudam" (RISTOFF, 2013b, p. 17). De acordo com o autor, os dados reforçam que, para a maioria dos estudantes, a dedicação exclusiva aos estudos não é uma opção. Em nível nacional, a situação de trabalho é mais evidente nos cursos de licenciaturas.

Segundo Ristoff (2013b, p. 17), dos 56\% dos estudantes brasileiros que indicaram trabalhar e estudar ao mesmo tempo, conforme o Questionário do ENADE, "[...] 27\% recebem ajuda da família para se sustentarem; $10 \%$ dizem que se sustentam com seu trabalho; $13,5 \%$ dizem que se sustentam e contribuem com o sustento da família; e 5,5\% dizem ser o principal responsável pelo sustento da família”.

Importante considerar também que a inserção dos trabalhadores brasileiros no mercado de trabalho e sua condição de renda ocorrem de maneiras diferenciadas e, por vezes, desiguais (IBGE, 2013a). Essas desigualdades podem ser encontradas entre as regiões brasileiras, nas diferenças entre homens e mulheres, pretos ou pardos e brancos, por exemplo. Conforme o IBGE (2013a), nos últimos anos reduziram as distâncias entre os rendimentos de homens e mulheres, mas permanece a condição de que as mulheres recebem menos, seja nos espaços formais ou informais de trabalho. "Em 2002, o rendimento médio das mulheres 
ocupadas, de 16 anos ou mais de idade, era equivalente a $70 \%$ do rendimento dos homens. Em 2012, essa relação passou para 73\%" (IBGE, 2013a, p. 147).

No que diz respeito aos trabalhos informais, essas diferenças de rendimento são mais acentuadas, sendo que a renda das mulheres nessa situação corresponde a 66\% da renda dos homens (IBGE, 2013a).

Com base no IBGE (2013a), a partir da década de 2000, diferente das décadas anteriores, um contingente maior de trabalhadores foi incorporado ao mercado de trabalho, e os dados indicam uma queda nas taxas de desocupação de $11,5 \%$, em 2002, para 5,4\%, em 2012. A maior taxa, em 2012, continua prevalecendo entre as mulheres e os jovens. Essa redução do desemprego, também associada ao aumento da renda da população, encontra-se associada à política de valorização do salário-mínimo nesse período. Além disso, “[...] nesta década, houve um aumento significativo da proporção de trabalhadores em trabalhos formais, que passou de $44,6 \%$, em 2002, para 56,9\%, em 2012" (IBGE, 2013a, p. 142).

No período considerado entre 2003 a 2012, o crescimento de empregos formais passou de 29,5 para 47,5 milhões. Dentre as regiões brasileiras, nas Regiões Sul e Centro-Oeste se destacam com um maior percentual de crescimento na condição de formalidade dentre as pessoas ocupadas, nesse período, como pode ser observado no gráfico 28 (IBGE, 2013a). 
Gráfico 28 - Percentual de pessoas de 16 anos de idade ou mais, ocupadas em trabalho formal, segundo as grandes regiões - 2002/2012

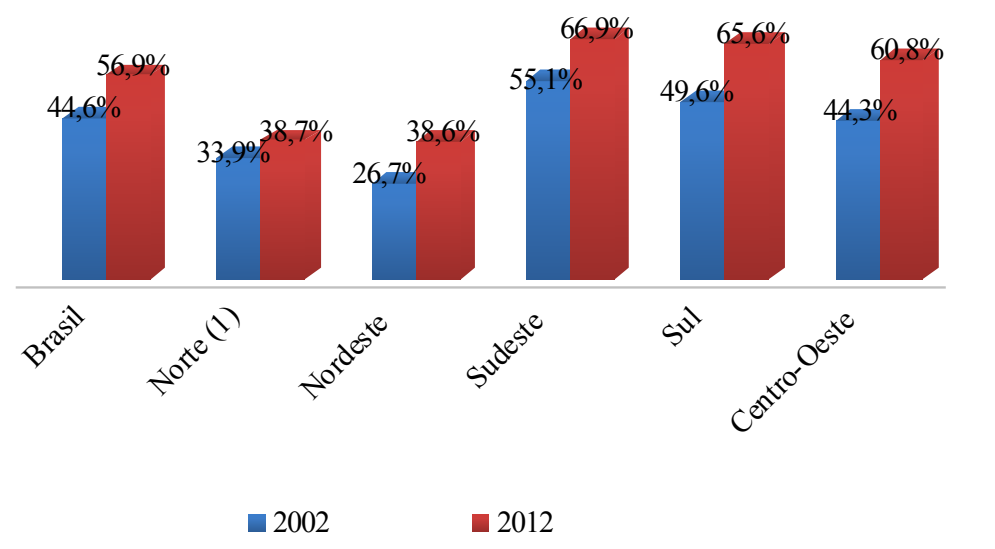

Fonte: IBGE (2013a, p. 143).

(1) Exclusive a população rural de Rondônia, Acre, Amazonas, Roraima, Pará e Amapá.

O trabalho informal também constitui uma característica marcante, pois, em 2012, atingia o percentual de $43,1 \%$ dos trabalhadores. Ainda mais marcante nas regiões Norte e Nordeste, nos Estados de Pará e Maranhão atingiu, respectivamente, os percentuais de 67,5\% e 74,5\%. Nas Regiões Sul e Centro-Oeste, nos Estados de Santa Catarina e Distrito Federal, respectivamente, o percentual foi menor, de apenas $26,9 \%$. Entre as pessoas de 16 anos ou mais ocupadas em trabalhos informais, segundo os grupos de idade, os maiores percentuais atingem os jovens na faixa etária de 16 a 24 anos, com 46,9\%, e idosos com 60 anos ou, 46,9\% (IBGE, 2013a).

Dentre a população economicamente ativa, a PNAD, em 2012, demonstrou que, considerando as pessoas de 10 anos ou mais, o Brasil tinha um percentual de 59,8\%. A Região Sul estava representada por $63,3 \%$ das pessoas na condição de ativas economicamente. 


\section{Renda}

No decurso da pesquisa também procurou-se identificar os dados sobre o quesito renda dos estudantes universitários da UFFS. A maioria dos estudantes possui renda familiar de até três salários-mínimos, conforme destaca o próximo gráfico. Os campi Cerro Largo, Laranjeiras do Sul e Realeza possuem um percentual de renda menor dentre os demais campi.

Gráfico 29 - Renda média mensal familiar dos estudantes da UFFS, por campus

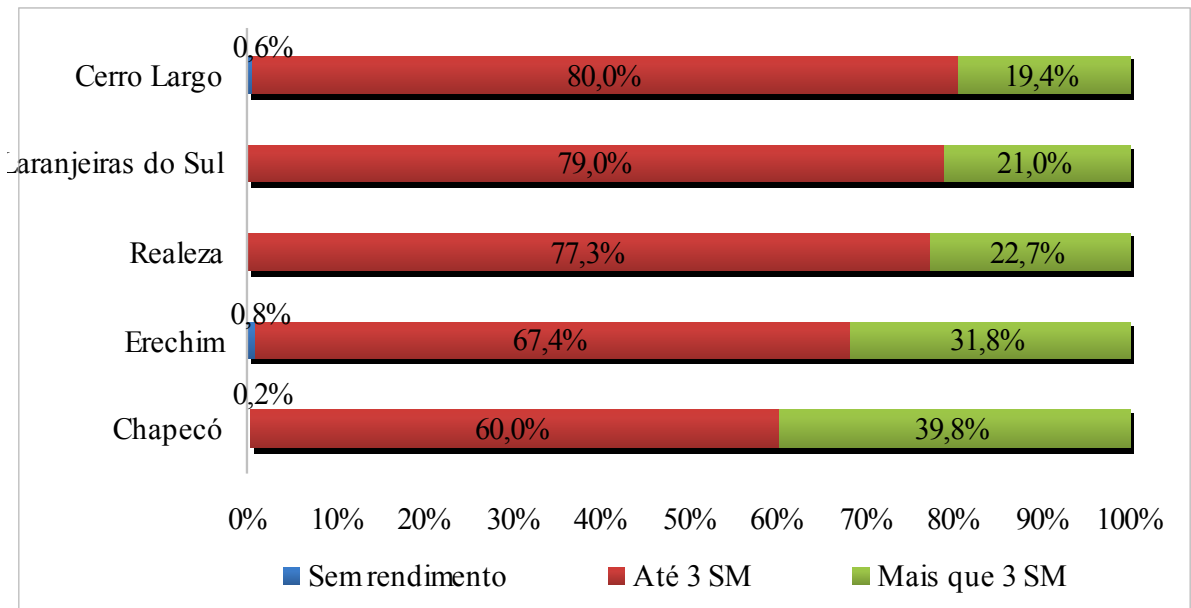

Fonte: Banco de Dados do Processo Seletivo 2012, DRA/PROGRAD/UFFS.

Nota: $\mathrm{SM}=$ salário-mínimo

Ao comparar os dados da população brasileira com a renda média mensal da família dos estudantes da UFFS ${ }^{16}$, é possível constatar que há algumas semelhanças, principalmente com relação à renda de até três (3) salários-mínimos, conforme o gráfico 30 . 
Gráfico 30 - Renda média mensal familiar dos estudantes da UFFS, da Região Sul e do Brasil

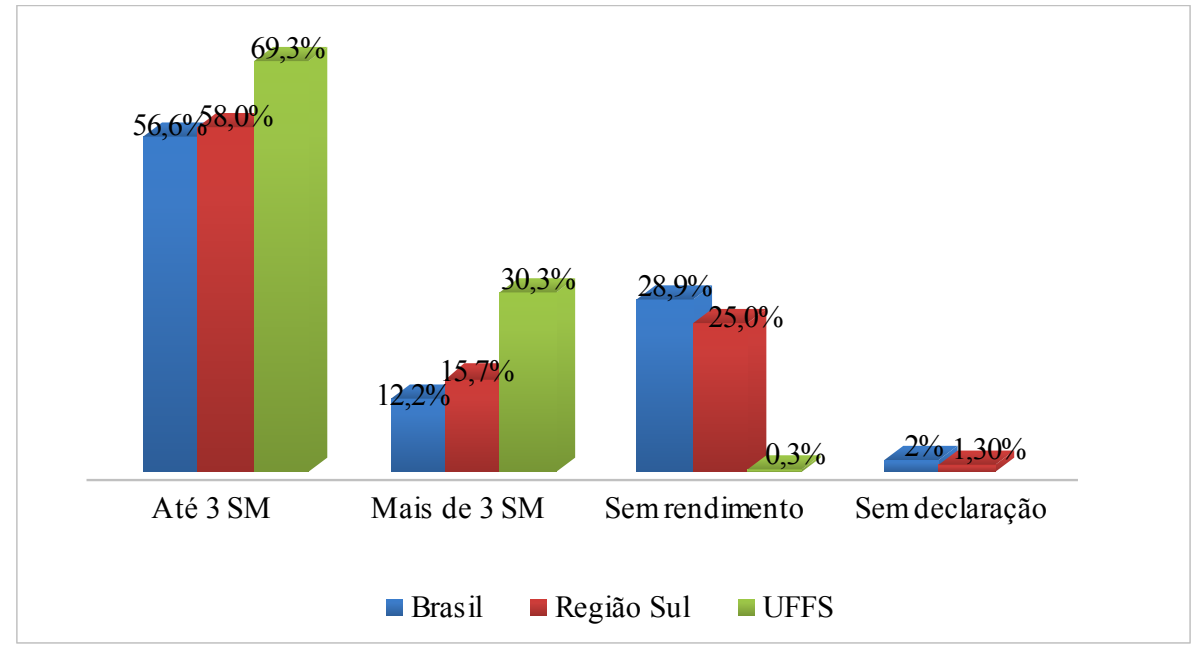

Fonte: Banco de Dados do Processo Seletivo 2012, DRA/PROGRAD/UFFS e PNAD 2012 (IBGE, 2014).

Nota: $\mathrm{SM}$ = salário-mínimo

Ao analisar os dados sobre a renda mensal apenas dos estudantes, constatou-se que $41,5 \%$ não possuem renda; $26,2 \%$ possuem até um salário-mínimo; 29,8\% de um a três salários-mínimos; e 2,5\% possuem acima de três salários-mínimos.

A pesquisa da Andifes/Fonaprace (2011) mostrou que, em nível nacional, a renda familiar de até três salários-mínimos dos estudantes das universidades federais é de 40,7\%. Na Região Sul, o percentual é de 31,3\%. Ristoff (2013b) aponta que, a partir do questionário socioeconômico do ENADE, 34\% dos estudantes sinalizaram possuir uma renda mensal familiar de até três salários-mínimos. Isso indica que houve um aumento de estudantes com a renda familiar nessa faixa, o que diminui as distâncias existentes entre campus universitário e a sociedade brasileira. Porém, ainda persistem algumas distâncias de renda, principalmente com relação a alguns cursos, entre os quais Medicina, Odontologia e Direito. 


\section{Gráfico 31 - Renda média mensal familiar dos estudantes da UFFS, por curso de graduação}

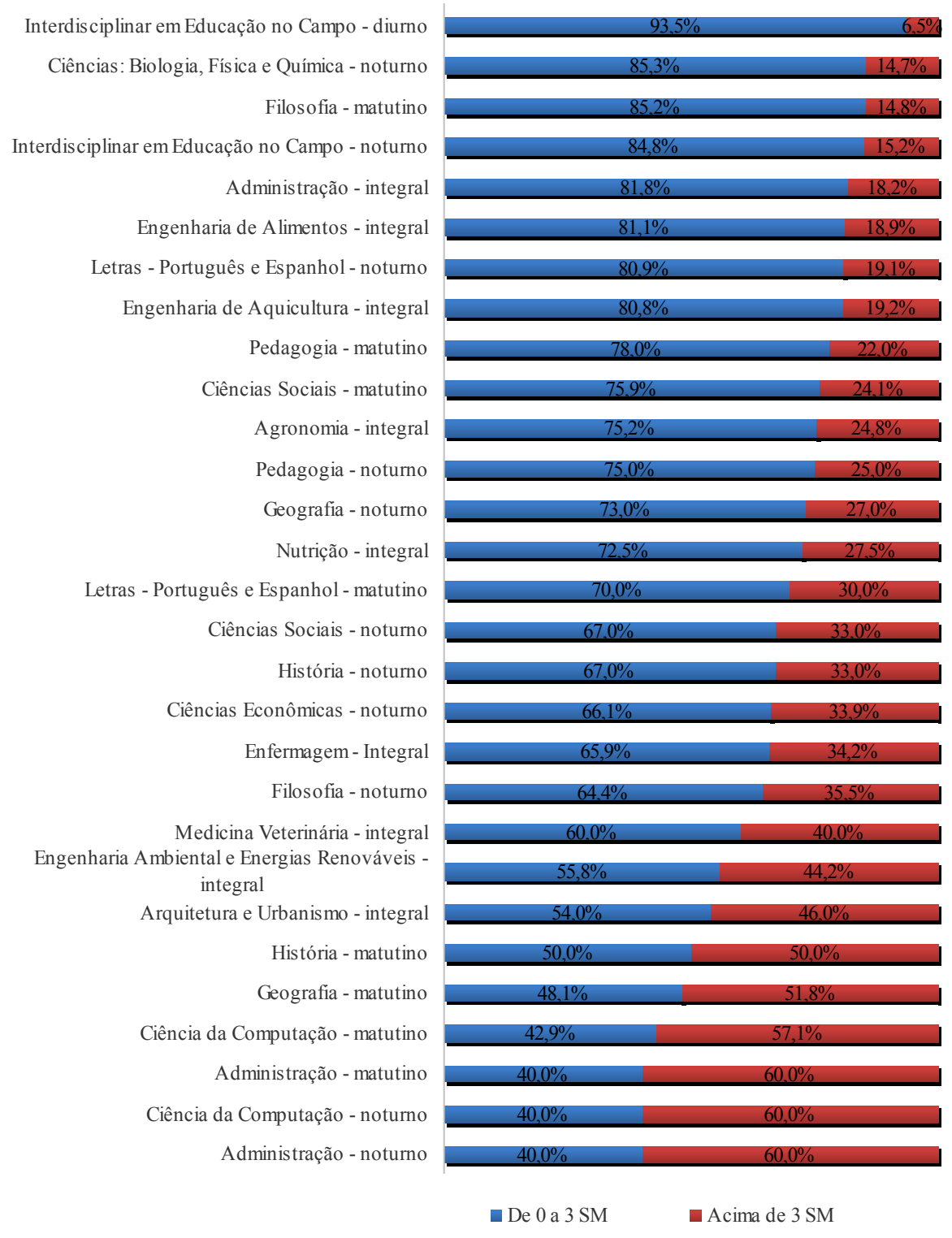

Nota: SM = salário-mínimo

Fonte: Banco de Dados do Processo Seletivo 2012, DRA/PROGRAD/UFFS. 
Na UFFS, ao olhar para a renda familiar ${ }^{17}$ e comparar entre os cur$\operatorname{sos}^{18}$, observou-se que a faixa de renda de zero a três salários-mínimos é uma característica predominantemente entre os estudantes distribuídos na maioria dos cursos, principalmente nas licenciaturas em Interdisciplinar em Educação no Campo (diurno e noturno); Ciências: Biologia, Física e Química e Filosofia (matutino). Os estudantes dos cursos de Ciências da Computação e Administração (matutino e noturno) possuem a renda familiar predominantemente acima de três salários-mínimos.

Ao relacionar esses dados sobre a renda com as demais universidades brasileiras, pode-se considerar que os estudantes das camadas populares estão adentrando na UFFS e isso se traduz na diminuição das desigualdades socioeconômicas que tradicionalmente fizeram parte da educação superior brasileira.

\section{TRAJETÓRIA ESCOLAR DOS INGRESSANTES}

Tendo em vista os objetivos desta pesquisa, buscou-se conhecer também a origem e a trajetória escolar dos estudantes da UFFS.

\section{Escolaridade dos pais dos ingressantes}

Uma característica importante a ser destacada sobre a trajetória escolar dos ingressantes da UFFS é a escolaridade dos seus pais ${ }^{19}$. Constatou-se que $44,5 \%$ estudaram somente até a $4^{\text {a }}$ série do ensino fundamental e somente $4,9 \%$ completaram o ensino superior e $1,7 \%$ possuem pós-graduação.

17 Para esta análise as variáveis foram reorganizadas em apenas duas: “de 0 a 3 SM" e "Acima de 3 SM". 
Gráfico 32 - Grau de escolaridade dos pais dos estudantes

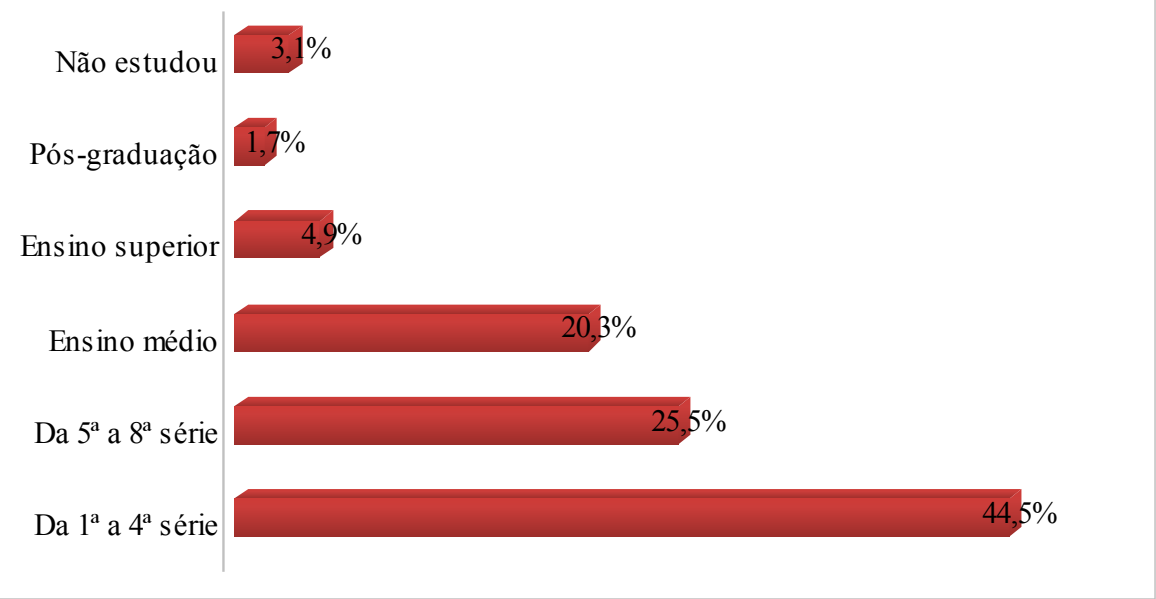

Fonte: Banco de Dados do Processo Seletivo 2012, DRA/PROGRAD/UFFS.

Quanto à escolaridade das mães identificou-se que o maior percentual também se concentrou nas primeiras séries do ensino fundamental: $36,1 \%$ estudaram até a $4^{\text {a }}$ série do antigo primário. Com relação à educação superior, 7,9\% das mães realizaram graduação e 5,0\%, pós-graduação. Observou-se que há uma tendência de maior escolaridade das mães em relação aos pais. 
Gráfico 33 - Grau de escolaridade das mães dos estudantes

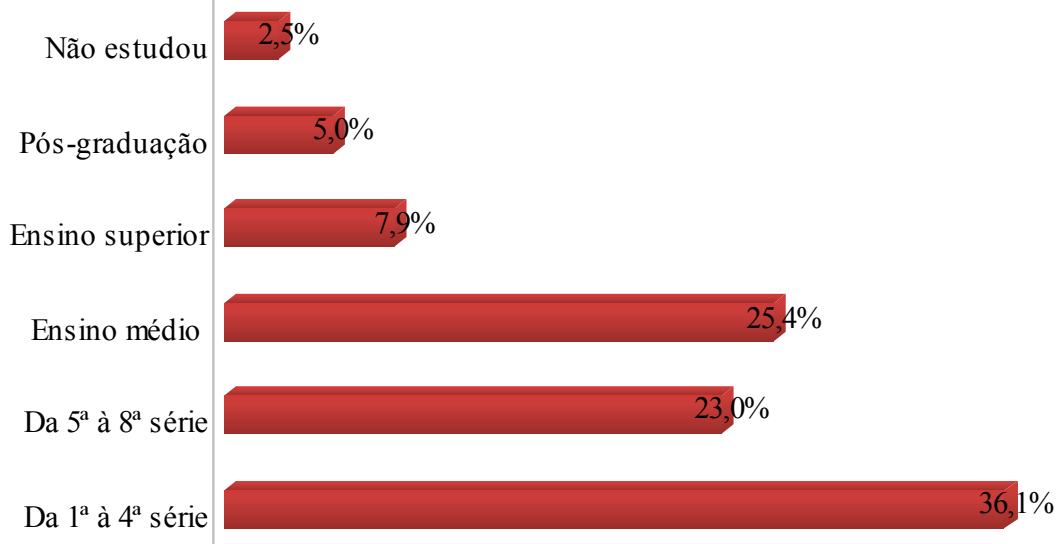

Fonte: Banco de Dados do Processo Seletivo 2012, DRA/PROGRAD/UFFS.

A pesquisa da Andifes/Fonaprace (2011) demonstrou que, em nível nacional, $28 \%$ dos pais e $33 \%$ das mães dos estudantes das universidades federais possuem nível superior completo.

Na UFFS, constatou-se que os pais dos ingressantes possuem poucos anos de escolarização, cujos dados se aproximam da realidade brasileira. Os estudantes, na sua maioria, além de frequentar o primeiro curso de graduação, constituem a primeira geração da família a acessar o ensino superior, conforme já apontavam os autores Rotta, Vitcel e Andrioli (2012). Essa experiência contribui para a redução das desigualdades sociais com base nos anos de escolaridade (RISTOFF, 2013b).

O gráfico 34 demonstra a evolução da média de anos de estudo entre a população feminina e masculina em idade acima de 18 anos, no período de 2005 a 2012, com base em dados da PNAD 2010 e apresentadas pelo MEC/INEP (2014a). Observa-se que os anos de estudo foram aumentando nesse período, para ambos os sexos, e que as mulheres mantiveram a média superior aos homens. 
Gráfico 34 - Média de anos de estudo da população feminina e masculina com idade acima de 18 anos no Brasil - 2005-2012

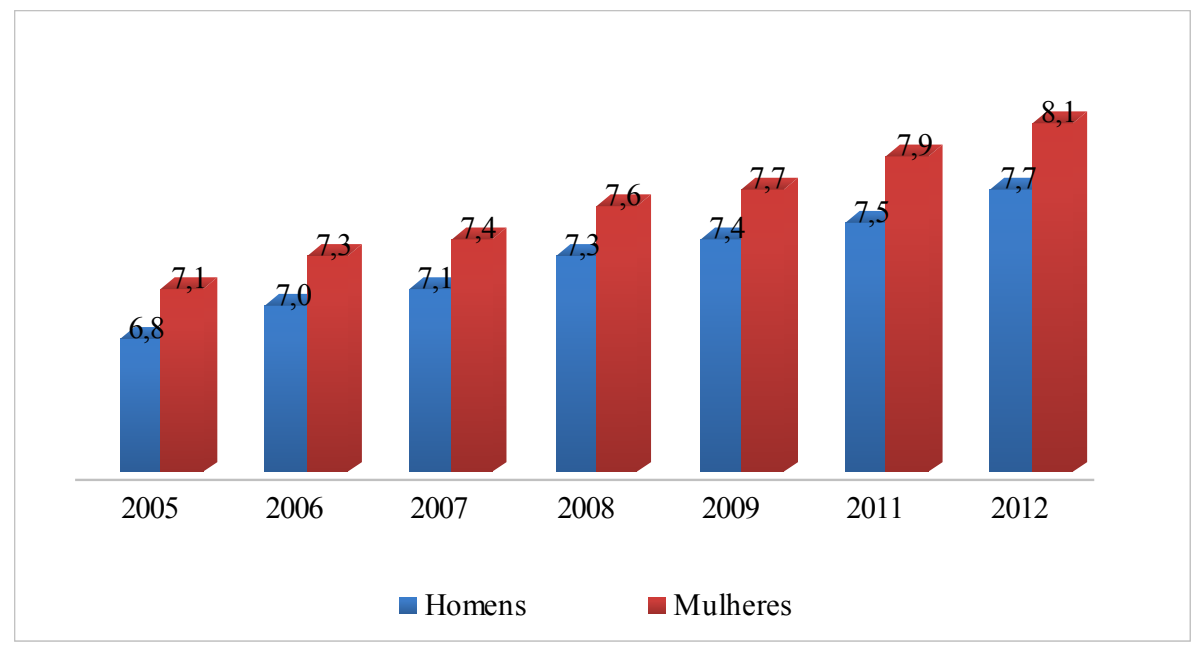

Fonte: MEC/INEP (2014a, p. 43).

Nota: "Como no ano de 2010 é realizado o Censo Demográfico, não se dispõe, nesse ano, dos dados da PNAD” (MEC/INEP, 2014a, p. 43).

Um estudo realizado pelo IPEA enfatizou as mudanças percebidas nos últimos vinte anos com relação à participação das mulheres no mercado de trabalho. Essa participação em 1992 era de 52,5\% e passou para $61 \%$ em 2012. Enquanto isso, a participação masculina teve uma redução de $89 \%$ para $83 \%$, respectivamente, nesse mesmo período. O estudo aponta que o aumento dos anos de estudo da mulher é um dos fatores que contribuiu para o ingresso no mercado de trabalho. A Região Sul é a que mais tem participação das mulheres no mercado de trabalho (BARBOSA, 2014). Conforme a autora,

[...] a educação tem um impacto positivo na probabilidade da mulher participar do mercado de trabalho brasileiro. Esse resultado é bastante acentuado para as mulheres com mais de onze anos de estudo. A probabilidade da mulher que se encontra nessa faixa educacional entrar no mercado de trabalho é de mais de $23 \%$ para cada ano analisado (BARBOSA, 2014, p. 38). 


\section{Origem escolar dos estudantes}

Indagados sobre o número de anos que levaram para concluir o ensino fundamental, a maioria dos ingressantes afirmou ter concluído em oito anos (79,9\%). E, quando questionados se haviam deixado de estudar durante o ensino fundamental, 96,9\% afirmou não ter deixado de estudar nesse nível de ensino.

Com relação à natureza administrativa da unidade escolar onde frequentaram o ensino fundamental, a maioria dos estudantes da UFFS declarou ter cursado a maior parte ou todos os anos em escola pública ${ }^{20}$, conforme demonstra o gráfico 35 .

Gráfico 35 - Natureza administrativa do ensino fundamental frequentado

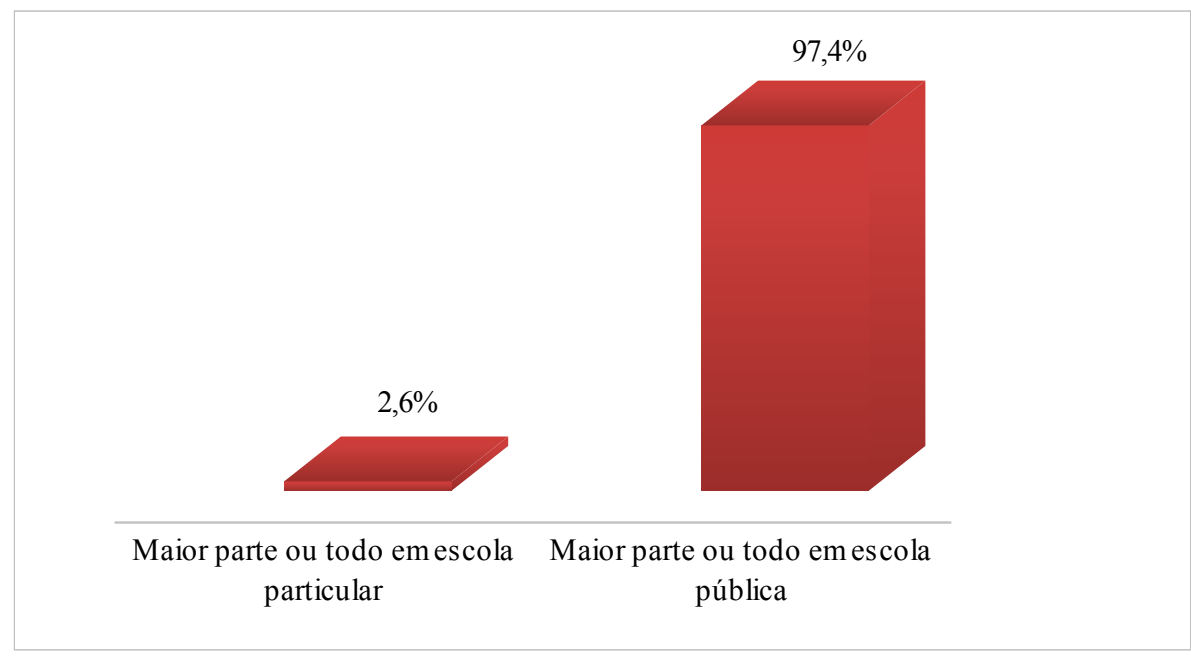

Fonte: Banco de Dados do Processo Seletivo 2012, DRA/PROGRAD/UFFS.

Na UFFS, por meio da política de ingresso adotada desde o início, constatou-se que a maioria dos estudantes declarou ter cursado as três 
séries na escola pública $(95,2 \%)$. O gráfico 36 demonstra a origem da escola do ensino médio, que é majoritariamente pública ${ }^{21}$.

Gráfico 36 - Natureza administrativa do ensino médio frequentado

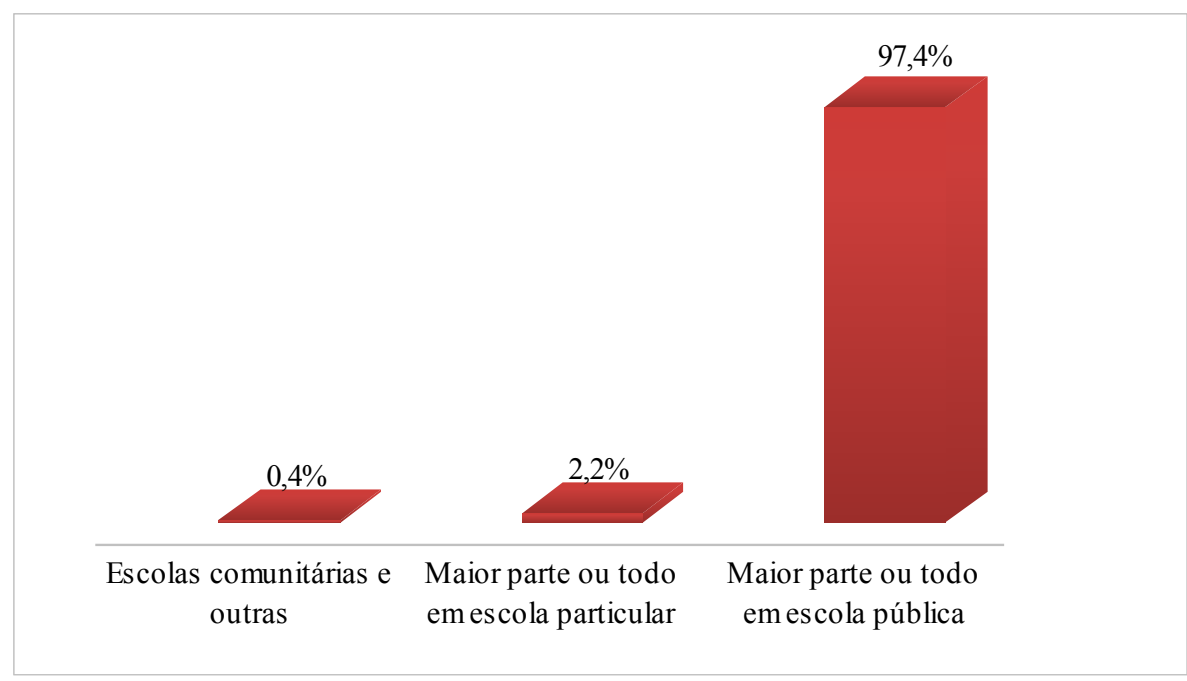

Fonte: Banco de Dados do Processo Seletivo 2012, DRA/PROGRAD/UFFS.

Na sequência, identificou-se que a maioria dos estudantes da UFFS realizou a matrícula pela primeira vez num curso de educação superior. Dos estudantes pesquisados, $75,8 \%$ responderam que não haviam frequentado e não estavam frequentando curso superior no momento da inscrição no Processo Seletivo da UFFS.

Quanto à modalidade de curso frequentado, os ingressantes na UFFS realizaram predominantemente o ensino médio de forma regular, sem ênfase em alguma área específica, conforme demonstra o gráfico 37. 
Gráfico 37 - Modalidade de curso de ensino médio frequentado ${ }^{22}$

Profissionalizante na área industrial, comércio ou serviços, e/ou saúde

Profissionalizante na área de magistério
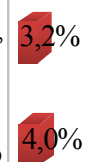

Supletivo ou equivalente

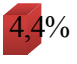

Profissionalizante na área agrícola

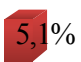

Regular, sem ênfase em qualquer área

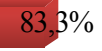

Fonte: Banco de Dados do Processo Seletivo 2012, DRA/PROGRAD/UFFS.

A pesquisa da Andifes/Fonaprace (2011) demonstrou que 87,4\% dos estudantes das universidades federais são oriundos majoritariamente do ensino médio regular.

Outra característica apontada é com relação à condição de bolsa no ensino médio. A maioria dos estudantes da UFFS indicou tê-lo cursado sem bolsa (97,4\%), 1,7\%, com bolsa integral, e 0,8\%, com bolsa parcial.

Com referência ao turno do ensino médio cursado, $70 \%$ dos estudantes da UFFS cursou em turno diurno.

No que se refere à procedência do ensino médio, em nível nacional, os dados da pesquisa da Andifes/Fonaprace (2011) indicaram que em 2010, $44,8 \%$ dos estudantes das IES públicas eram oriundos exclusivamente de escola pública. Na Região Sul, o percentual é de 50,6\%. A Região Norte é a que mais se destacou, com 71,5\%.

O Censo da Educação Básica de 2012 demonstrou que o percentual de matrículas no ensino médio no Brasil era de $87,3 \%$. Ao comparar os 
dados das matrículas do ensino médio com as matrículas do ensino superior, em 2012, é possível perceber a inversão que ocorre, pois 73\% das matrículas do ensino superior são realizadas nas instituições privadas, conforme demonstra o gráfico 40 (MEC/INEP, 2014c).

Gráfico 38 - Natureza administrativa das matrículas do ensino médio e superior no Brasil e a Região Sul, em 2012
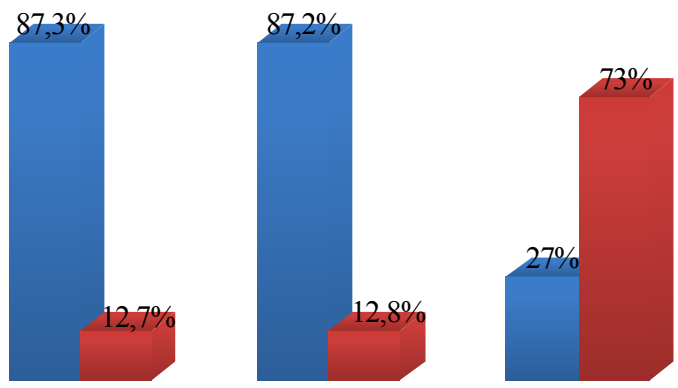

Ens. Médio Brasil Ens. Médio Região Ed. Superior Brasil Sul

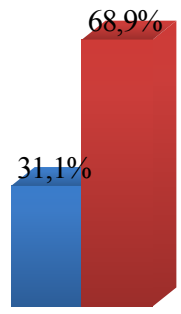

Ed. Superior Região Sul

Público

- Privado

Fonte: Banco de Dados do Processo Seletivo 2012, DRA/PROGRAD/UFFS e MEC/INEP (2014b; 2014c).

Os dados revelaram que a grande demanda oriunda do ensino médio público não estava sendo absorvida na educação superior pública, o que revela uma das facetas do elitismo na educação superior, pois, de um lado, a maioria de estudantes faz a educação básica na escola pública, porém, ao chegar a um curso universitário, essa maioria nem sempre acessa a universidade pública. Situa-se que a Lei no $12.711 / 2012$, ao garantir a reserva de vagas de $50 \%$ nas instituições federais de ensino para estudantes oriundos da escola pública teve o propósito de reduzir essas desigualdades. Conforme destaca Ristoff (2013b, p. 22):

Ainda que sua aplicação seja restrita, a pequena parte do conjunto de vagas disponíveis a cada ano, sua implantação pode pavimentar o caminho para que as políticas mais agressivas de inclusão tornem-se 
politicamente viáveis e aproximem os percentuais dos estudantes de educação superior oriundos da escola pública da proporção de $87 \%$ que representam no sistema educacional brasileiro.

A partir da "Lei das Cotas", a avaliação é de que, se em 2012 havia 31\% das instituições federais de ensino superior com alguma ação afirmativa, a partir do ano de 2013, todas as instituições passaram a tê-la, em cumprimento à lei. Feres Júnior et al. (2013) ressaltam que o total de vagas reservadas pelas universidades federais, de acordo com os critérios de escola pública, associado com a renda e o pertencimento étnico (pretos, pardos e indígenas), no primeiro ano de aplicação da lei, foi 31,5\%. A Região Sul foi a que mais se aproximou das metas estabelecidas pela nova legislação, conforme demonstra o gráfico 39.

Gráfico 39 - Variação no percentual médio do total de vagas reservadas entre 2012 e 2013, de acordo com a região da universidade

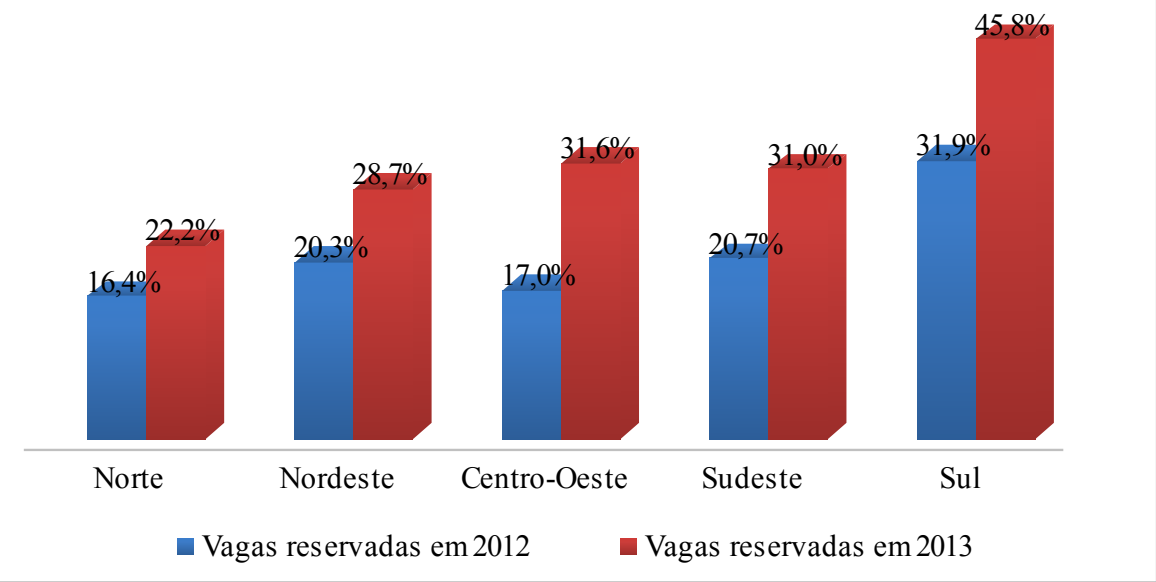

Fonte: Feres Júnior et al. (2013, p. 23).

A partir dessa análise, é possível constatar a contribuição da UFFS com a inclusão de estudantes oriundos da escola pública. Os números demonstram o compromisso da IES com a democratização do acesso à 
educação superior, num patamar superior ao que é almejado pela própria "Lei das Cotas". Conforme Nierotka e Trevisol (2014, p. 16), "os egressos da escola pública estão na universidade, formam a quase totalidade da comunidade acadêmica da UFFS e colocam inúmeros desafios, os quais demandam pesquisa, compreensão crítica e intervenção".

As tabelas 5 e 6 apresentam os percentuais de escola pública dos ingressantes na UFFS nos seus primeiros cinco anos, considerando todas as formas de entradas ${ }^{23}$. A primeira delas destaca a média por ano, e a segunda, a média entre os 5 anos, por campus.

Tabela 5 - Percentual de estudantes da UFFS oriundos do ensino médio público (2010-2014)

\begin{tabular}{l|l}
\hline Ano & Escola Pública (\%) \\
\hline 2010 & 94,0 \\
\hline 2011 & 94,8 \\
\hline 2012 & 93,6 \\
\hline 2013 & 92,0 \\
\hline 2014 & 90,4 \\
\hline
\end{tabular}

Fonte: Sistema de Gestão Acadêmica (SGA) / Diretoria de Registro Acadêmico/UFFS, 2014.

Tabela 6 - Média do percentual de escola pública entre os campi da UFFS (2010-2014)

\begin{tabular}{l|l}
\hline Campus & Escola Pública (\%) \\
\hline Chapecó & 90,5 \\
\hline Laranjeiras do Sul & 96,7 \\
\hline Realeza & 97,3 \\
\hline Cerro Largo & 94,5 \\
\hline Erechim & 89,8 \\
\hline Passo Fundo $^{24}$ & 86,6 \\
\hline
\end{tabular}

Fonte: Sistema de Gestão Acadêmica (SGA)/Diretoria de Registro Acadêmico/UFFS, 2014.

Constatou-se que a média geral de escola pública na UFFS se manteve sempre acima de $90 \%$. Ao olhar para os campi percebeu-se uma

23 Os dados foram gerados e disponibilizados pela Diretoria de Registro Acadêmico. Para essas tabelas estão sendo consideradas todas as formas de ingresso na UFFS: ENEM; processo seletivo especial; processo seletivo especial (PROHAITI); retorno de aluno abandono; retorno de graduado; transferência ex-offício; transferência externa e transferência interna. Conforme a DRA, a informação sobre a escola pública é buscada junto ao histórico escolar do ensino médio.

24 A média foi considerada apenas entre os anos de 2013 e 2014, a partir da criação do Campus e do curso de Medicina. 
distribuição mais variada, principalmente com relação ao Campus Passo Fundo, em que se constatou o menor percentual. Os campi de Laranjeiras do Sul e Realeza aparecem com os maiores percentuais de graduandos oriundos da escola pública.

\section{Turno e modalidade dos cursos de graduação cursados pelos estudantes da UFFS}

Na UFFS, no ano de 2012, do total dos estudantes matriculados, 50,6\% estavam vinculados em cursos noturnos ${ }^{25}$ e $49,4 \%$ em cursos diurnos. Dos estudantes vinculados ao turno diurno, $14,3 \%$ estudavam no período matutino e $35,1 \%$ nos períodos matutino e vespertino, estando esses últimos vinculados à modalidade de curso integral.

O gráfico 40 apresenta os dados sobre os turnos das matrículas de graduação da UFFS, comparados com todas as IES do Brasil, com as IES somente públicas e com as IES da Região Sul.

No que tange ao turno dos cursos de graduação presencial, os dados do Censo da Educação Superior de 2012 demonstraram que, em âmbito nacional, a maioria das matrículas na graduação presencial está vinculada a cursos, cujo turno é noturno $(63,1 \%)$. Se forem consideradas somente as Universidades Federais, esse dado se diferencia, porque a oferta ocorre predominantemente no turno diurno (61,5\%). Em termos regionais, as participações das matrículas noturnas ocorrem principalmente nas regiões Sudeste, Sul e Centro-Oeste com os percentuais de 68,2\%, 66,1\% e 62,4\%, respectivamente (MEC/INEP, 2014b). 
Gráfico 40 - Turno das matrículas de graduação presencial no Brasil, Região Sul e UFFS

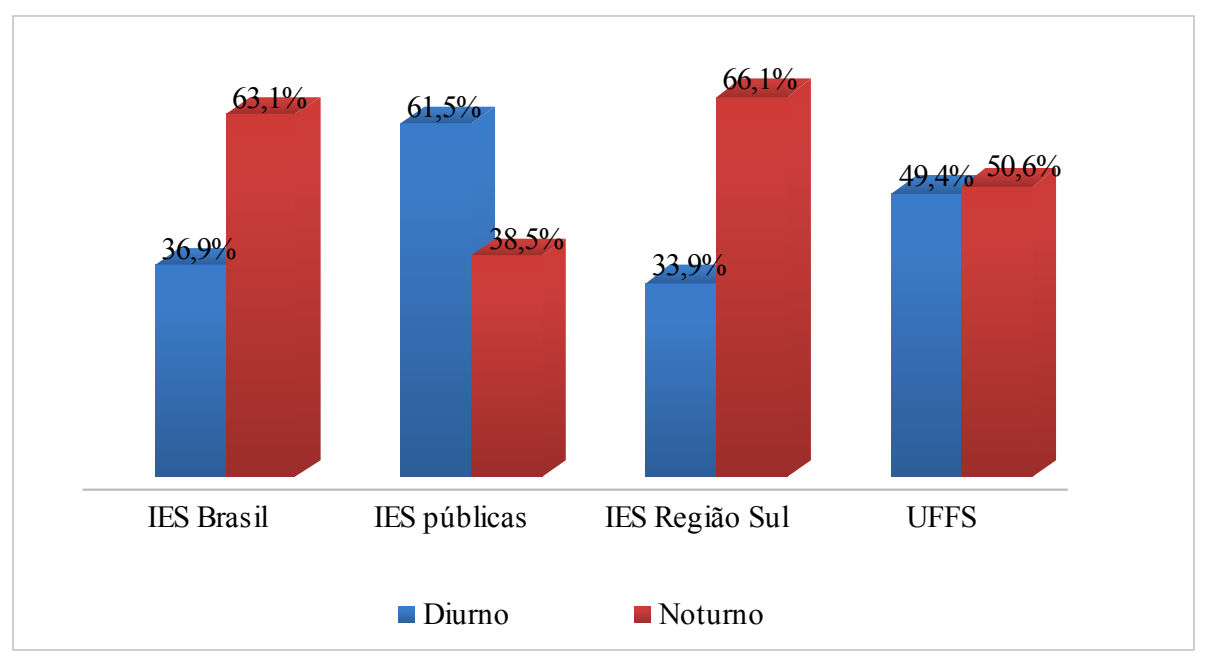

Fonte: Banco de Dados do Processo Seletivo 2012, DRA/PROGRAD/UFFS e MEC/INEP (2014b).

Ainda, segundo dados do Censo da Educação Superior de 2012, no que se refere às instituições privadas, a maioria dos estudantes nos cursos de graduação prevalece matriculada no turno noturno, com um percentual de $73,2 \%$. Por sua vez, a rede pública concentra a maioria dos cursos de graduação presencial no turno diurno. As IES públicas estaduais possuem mais da metade das matrículas em cursos presenciais no turno diurno, e as IES públicas municipais se aproximam mais das privadas (MEC/INEP, 2014b).

Com relação à modalidade dos cursos de graduação, do total de 2.123 matrículas, em 2012, a maioria se concentra em cursos de licenciaturas (54\%). Essa característica se diferencia das demais IFES, quando analisadas num contexto mais abrangente, em âmbito nacional e regional, conforme aponta o gráfico 41 . 
Gráfico 41 - Vinculação das matrículas de graduação, segundo modalidade de curso, no Brasil, Região Sul e UFFS

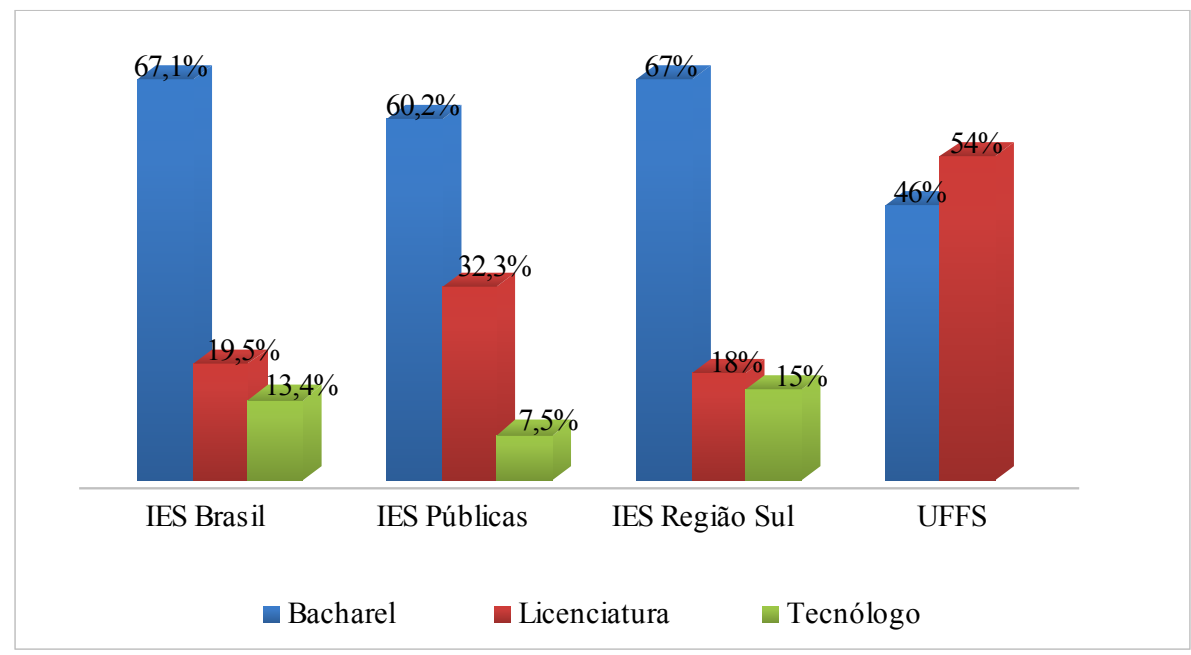

Fonte: Banco de Dados do Processo Seletivo 2012, DRA/PROGRAD/UFFS; MEC/INEP (2014b).

Consoante à modalidade de curso, os dados do Censo da Educação Superior assinalam que, de um total de 7.037.688 matrículas realizadas em 2012 nas IES brasileiras, $67,1 \%$ estão vinculadas a cursos de bacharelado. Dentre as IES públicas (federais, estaduais e municipais), o percentual é menor, representado por 60,2\%. Na Região Sul, os cursos na modalidade bacharelado também constituem a maioria (MEC/INEP, 2014b).

Ao analisar o período de 2009 a 2012, conforme aponta o MEC/ INEP (2014a, p. 60), ocorreu uma maior elevação nos cursos a distância, "com crescimento registrado de 32,9\% de 2009 a 2012, com uma média de crescimento de aproximadamente $10 \%$ ao ano. As matrículas de cursos presenciais apresentaram média anual de variação positiva de $5 \%$ no mesmo período".

Os cursos tecnológicos, nesse mesmo período, registraram o maior crescimento, com uma média anual de 11,6\%. As matrículas nos cursos de licenciatura registraram um aumento, em média, de pouco mais de $4 \%$ ao ano. Nos cursos de bacharelado ocorreu uma variação positiva de 4,6\%, conforme verificado o crescimento de 2011 para 2012 (MEC/INEP, 2014a). 


\section{SITUAÇÃO DE MATRÍCULA DOS INGRESSANTES}

Ao conceber a presente pesquisa, julgou-se importante inserir uma categoria de análise voltada para analisar a trajetória acadêmica dos ingressantes na UFFS, tomando como referência o ano de ingresso, 2012. Procurou-se analisar a permanência ou não desses estudantes num período entre os dois anos seguintes do seu ingresso ${ }^{26}$ (2012 a 2014).

A partir dos dados analisados, constatou-se que, dos 2.123 ingressantes na UFFS, em 2012, a partir do processo seletivo regular, a maioria ainda permanece com a matrícula ativa em 2014, totalizando 1.404 estudantes $^{27}(66,1 \%)$, e $719(33,9 \%)$ se encontram na condição de desistente ${ }^{28}$, conforme demonstra o gráfico 42 .

Gráfico 42 - Situação acadêmica dos ingressantes na UFFS

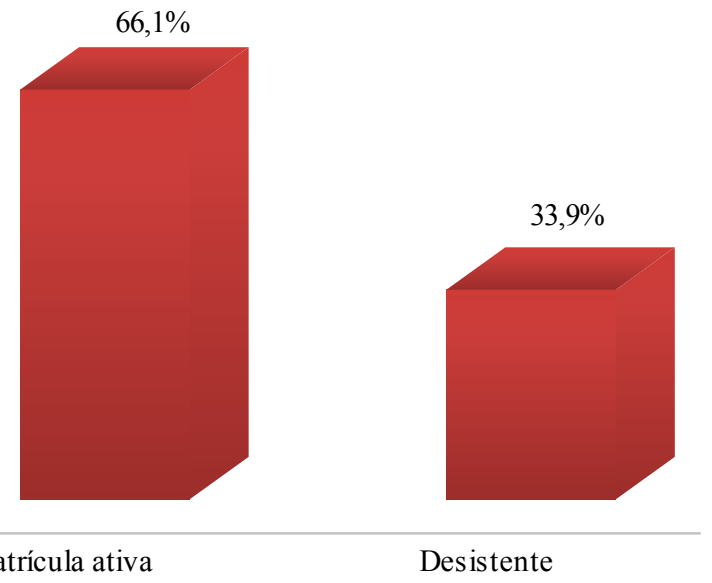

Fonte: Banco de Dados do Processo Seletivo 2012, DRA/PROGRAD/UFFS.

26 Foi considerado o primeiro semestre do ano de 2012 até o primeiro semestre de 2014, momento em que os dados foram fornecidos pela Diretoria de Registro Acadêmico da UFFS.

$27 \mathrm{Na}$ categoria matrícula ativa estão contemplados os estudantes, cuja situação acadêmica se encontra nas seguintes condições: matrícula ativa; transferência interna, matrícula aditada e matrícula trancada.

$28 \mathrm{Na}$ categoria desistente estão contemplados os estudantes, cuja situação acadêmica encontra-se nas seguintes condições: matrícula cancelada; eliminado; aluno desistente e aluno transferido. 
No que se refere aos ingressantes considerados desistentes na UFFS, os tipos de desistências estão relacionados a qualquer uma das seguintes modalidades: matrícula cancelada ${ }^{29}$, matrícula eliminada ${ }^{30}$, aluno desistente $^{31}$ e transferido ${ }^{32}$. Ao olhar somente para o grupo dos desistentes $(33,9 \%)$, a forma de registro predominante em relação ao tipo de desistência é o cancelamento da matrícula, pois representa um percentual de $69,4 \%$, seguido pela desistência, 18,2\%, matrícula eliminada, $11,7 \%$ e transferência, $0,7 \%$.

Outra possibilidade de análise é observar o percentual de matrículas ativas e de desistentes dos ingressantes de cada campus da UFFS, conforme é apresentado no gráfico 43. Lê-se do gráfico 43 que a proporção de estudantes com matrícula ativa é maior que a de desistentes em todos os campi. Por exemplo, no Campus Cerro Largo, dos 345 ingressantes em $2012,73,0 \%$ permanecem com a matrícula ativa e $27,0 \%$ são desistentes.

Nota-se, também, que os campi Cerro Largo, Realeza e Erechim apresentam índices de matrículas ativas superiores à média de $66,1 \%$, percebida para a UFFS.

Os campi Laranjeiras do Sul e Chapecó apresentam os percentuais de estudantes na condição de desistentes superiores à média geral da UFFS, de $33,9 \%$.

\footnotetext{
29 É a situação em que os estudantes não renovam o vínculo com a UFFS, ou seja, que não fazem rematrícula e nem o ajuste de matrícula no período estabelecido pelo calendário acadêmico. A matrícula é cancelada automaticamente pela UFFS. Está regulamentado pelo art. 52 da Resolução 04/2014 - CONSUNI/CGRAD. Os estudantes podem retornar a serem alunos regulares por meio do processo seletivo de retorno de aluno-abandono (UFFS, 2014a).

30 Esta situação é aplicada ao estudante, ingressante pelo processo seletivo principal (ENEM), que não frequenta as aulas nos cinco primeiros dias letivos do semestre em questão ou solicita desistência de sua matrícula antes do início das aulas. Neste caso, como o aluno não constitui vínculo, não poderá retornar por aluno-abandono. É regulamentado pelo art. 43 da Resolução 04/2014 - CONSUNI/CGRAD (UFFS, 2014a).

31 É quando o estudante solicita formalmente a desistência de sua matrícula na UFFS, perdendo, com isso, o vínculo com a instituição. É regulamentado pelo art. 63 da Resolução 04/2014 - CONSUNI/CGRAD (UFFS, 2014a).

32 Ocorre quando os estudantes solicitam e conseguem, em outra IES, vaga por Transferência Externa (UFFS, 2014a).
} 
Gráfico 43 - Situação acadêmica dos ingressantes na UFFS, por campus

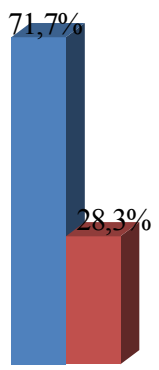

Realeza

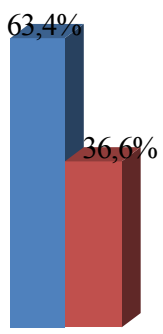

Chapecó

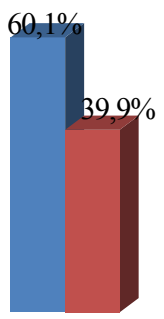

Laranjeiras do Sul

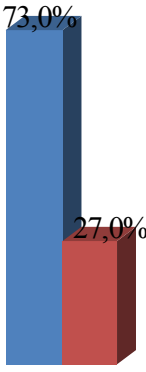

Cerro Largo

Erechim

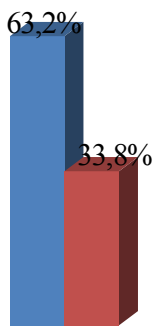

Matrícula ativa $\square$ Desistente

Fonte: Banco de Dados do Processo Seletivo 2012, DRA/PROGRAD/UFFS.

O gráfico 43 apresentou a condição de matrícula em relação à proporção de estudantes de cada campus. A tabela 7 apresenta outra possibilidade de analisar essa informação, considerando a proporção de estudantes de cada campus em relação ao total da UFFS. Dessa forma, observa-se que o Campus Chapecó concentra a maior proporção de estudantes com a matrícula ativa em relação ao universo de $66,1 \%$, com um percentual de $24,8 \%$. Em seguida, situam-se os campi Erechim, Cerro Largo, Realeza e Laranjeiras do Sul, respectivamente.

Tabela 7 - Situação acadêmica detalhada, por campus da UFFS

\begin{tabular}{l|l|l|l|l}
\hline & & Desistente & Matrícula ativa & Total \\
\hline \multirow{4}{*}{ Chapecó } & Contagem & 303 & 526 & 829 \\
\cline { 2 - 5 } & \% dentro de Campus & $36,6 \%$ & $63,4 \%$ & $100,0 \%$ \\
\cline { 2 - 5 } & \% dentro de situação de matrícula & $42,1 \%$ & $37,5 \%$ & $39,0 \%$ \\
\cline { 2 - 5 } & \% do Total & $14,3 \%$ & $24,8 \%$ & $39,0 \%$ \\
\hline \multirow{2}{*}{$\begin{array}{l}\text { Laranjeira Sul } \\
\text { do }\end{array}$} & Contagem & 112 & 169 & 281 \\
\cline { 2 - 5 } & \% dentro de Campus & $39,9 \%$ & $60,1 \%$ & $100,0 \%$ \\
\cline { 2 - 5 } & \% dentro de situação de matrícula & $15,6 \%$ & $12,0 \%$ & $13,2 \%$ \\
\cline { 2 - 5 } & \% do Total & $5,3 \%$ & $8,0 \%$ & $13,2 \%$ \\
\hline
\end{tabular}




\begin{tabular}{|c|c|c|c|c|}
\hline & & Desistente & Matrícula ativa & Total \\
\hline \multirow[t]{4}{*}{ Realeza } & Contagem & 76 & 193 & 269 \\
\hline & \% dentro de Campus & $28,3 \%$ & $71,7 \%$ & $100,0 \%$ \\
\hline & \% dentro de situação de matrícula & $10,6 \%$ & $13,7 \%$ & $12,7 \%$ \\
\hline & $\%$ do Total & $3,6 \%$ & $9,1 \%$ & $12,7 \%$ \\
\hline \multirow{4}{*}{$\begin{array}{l}\text { Cerro } \\
\text { Largo }\end{array}$} & Contagem & 93 & 252 & 345 \\
\hline & \% dentro de Campus & $27,0 \%$ & $73,0 \%$ & $100,0 \%$ \\
\hline & \% dentro de situação de matrícula & $12,9 \%$ & $17,9 \%$ & $16,3 \%$ \\
\hline & $\%$ do Total & $4,4 \%$ & $11,9 \%$ & $16,3 \%$ \\
\hline \multirow[t]{4}{*}{ Erechim } & Contagem & 135 & 264 & 399 \\
\hline & $\%$ dentro de Campus & $33,8 \%$ & $66,2 \%$ & $100,0 \%$ \\
\hline & $\%$ dentro de situação de matrícula & $18,8 \%$ & $18,8 \%$ & $18,8 \%$ \\
\hline & $\%$ do Total & $6,4 \%$ & $12,4 \%$ & $18,8 \%$ \\
\hline \multirow[t]{4}{*}{ Total } & Contagem & 719 & 1404 & 2123 \\
\hline & \% dentro de Campus & $33,9 \%$ & $66,1 \%$ & $100,0 \%$ \\
\hline & \% dentro de situação de matrícula & $100,0 \%$ & $100,0 \%$ & $100,0 \%$ \\
\hline & $\%$ do Total & $33,9 \%$ & $66,1 \%$ & $100,0 \%$ \\
\hline
\end{tabular}

Fonte: Gerado pelo SPSS e organizado a partir do Banco de Dados do Processo Seletivo 2012, DRA/ PROGRAD/UFFS.

Entre os estudantes que permanecem na UFFS, com a condição de "matrícula ativa" $(66,1 \%)$, procurou-se estabelecer uma relação com os cursos de graduação em que foram matriculados. Os estudantes que mais permanecem nessa condição estão vinculados aos cursos de bacharelado em Enfermagem, Medicina Veterinária e Agronomia, conforme se observa no próximo gráfico. 
Gráfico 44 - Percentuais de "matrícula ativa" dos estudantes, por curso

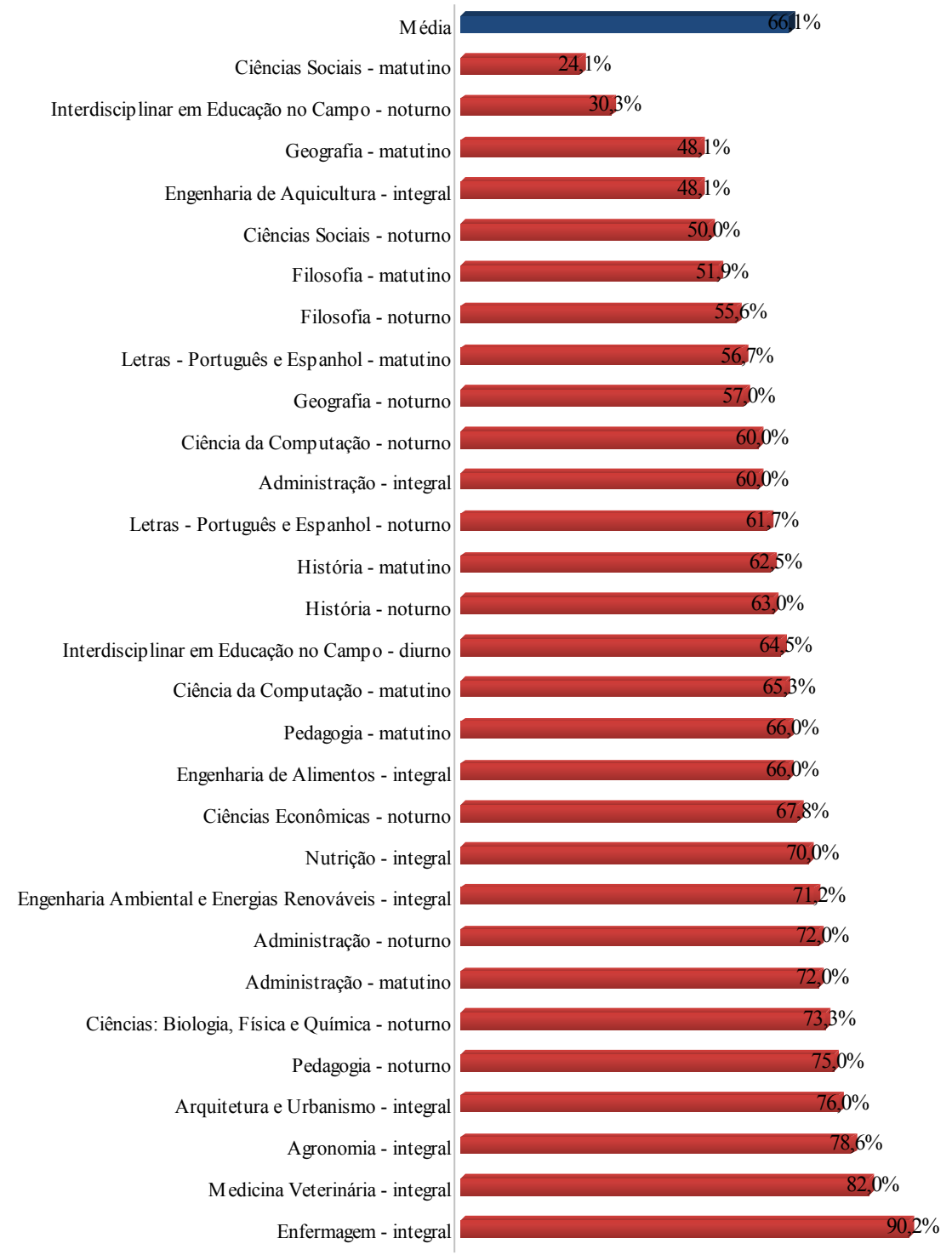

Fonte: Banco de Dados do Processo Seletivo 2012, DRA/PROGRAD/UFFS.

Com base no gráfico 45, observa-se entre os cursos que apresentam maior percentual de estudantes na condição acadêmica de "desistente" 


\section{estão principalmente as licenciaturas em Ciências Sociais (matutino), In- terdisciplinar em Educação no Campo (noturno), Geografia (matutino) e o curso bacharel em Engenharia de Aquicultura (integral).}

\section{Gráfico 45 - Percentuais de estudantes “desistentes”, por curso}

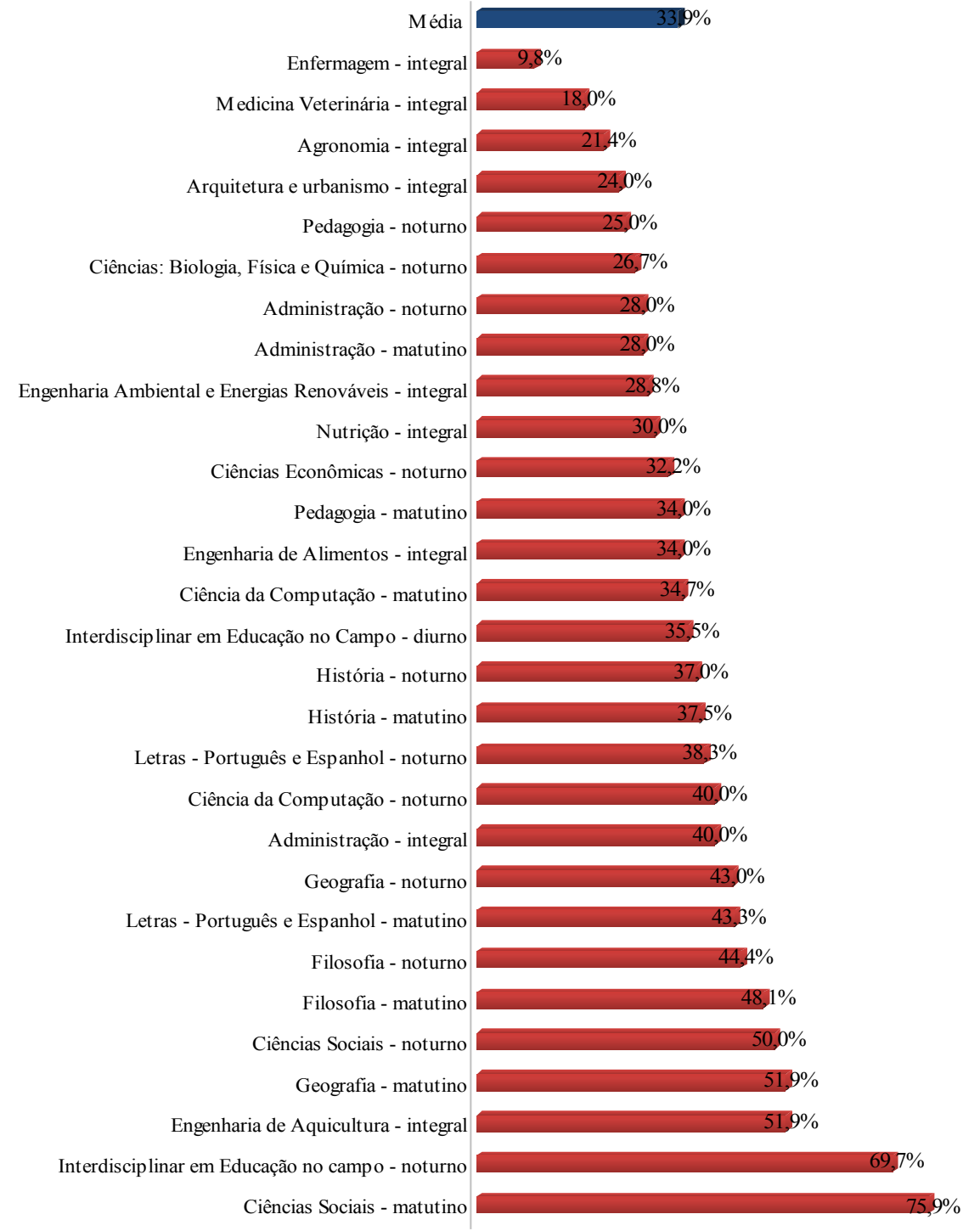


Ao olhar para a condição feminina e masculina e sua relação com a desistência e a matrícula ativa, conforme o gráfico 46, percebeu-se que as estudantes do sexo feminino são as que mais permanecem na UFFS, o que configura a característica já mencionada de que as mulheres tendem a possuir mais anos de escolaridade aos homens.

Gráfico 46 - Situação acadêmica dos ingressantes, de acordo com o sexo

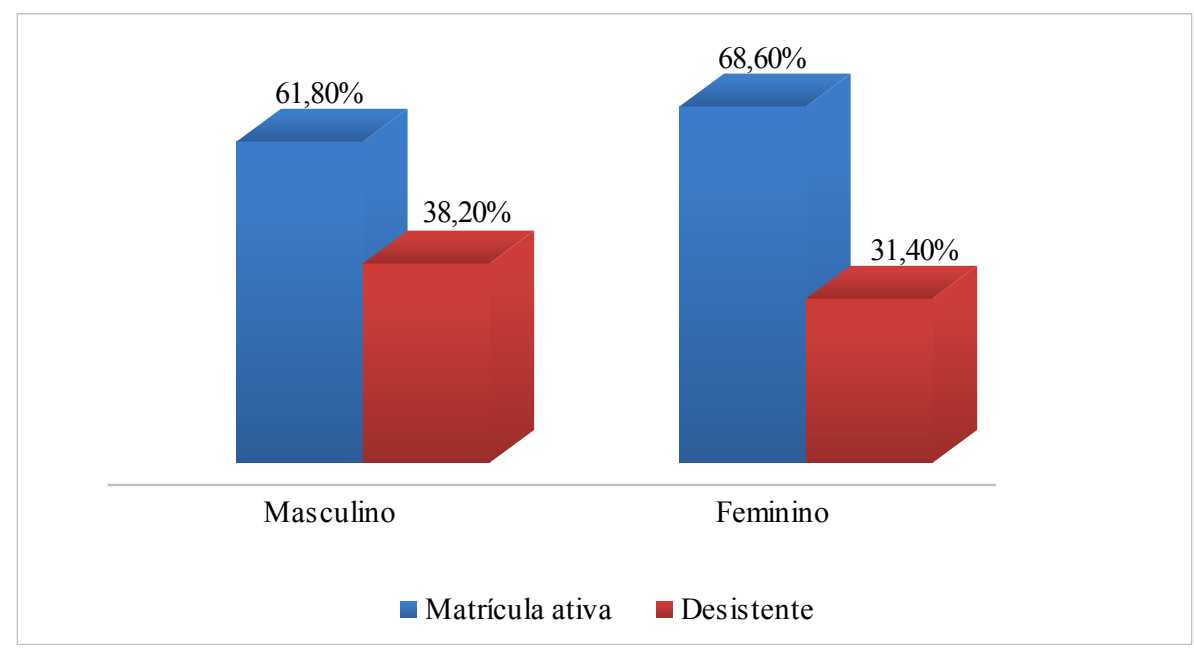

Fonte: Banco de Dados do Processo Seletivo 2012, DRA/PROGRAD/UFFS.

Com relação à faixa etária dos estudantes, observou-se que do grupo de ingressantes com até 24 anos a maioria mantém sua matrícula ativa (gráfico 47). No entanto, os 30,9\% que desistem representam também o maior percentual de desistentes do total de ingressantes. 
Gráfico 47 - Situação acadêmica e faixa etária dos estudantes

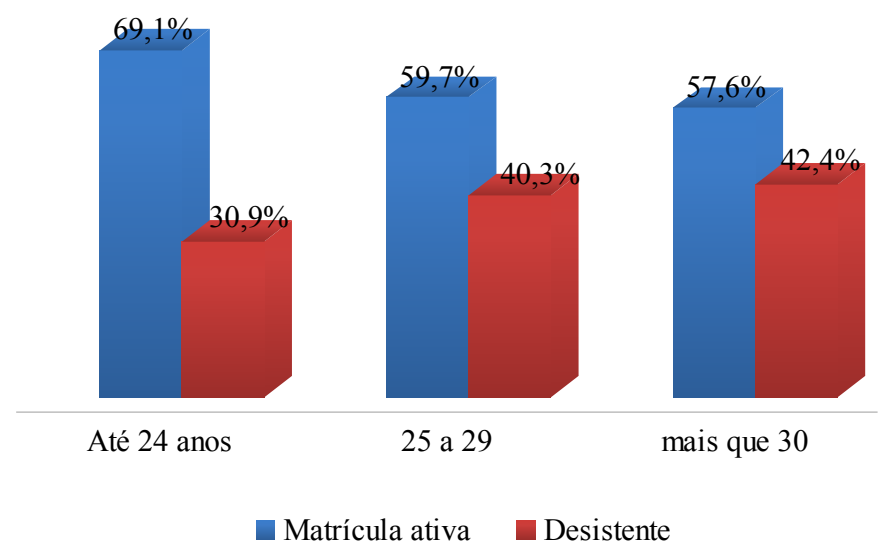

Fonte: Banco de Dados do Processo Seletivo 2012, DRA/PROGRAD/UFFS.

Com relação ao quesito étnico e a situação de matrícula, observou-se que os percentuais não apresentam muitas alterações, havendo uma leve tendência entre os estudantes desistentes pertencerem ao grupo dos autodeclarados não brancos (pardos, pretos, indígenas e/ou amarelos), de $36,9 \%$ para $33,5 \%$, que pertence ao grupo autodeclarado branco.

Uma outra abordagem pertinente é com relação à condição de trabalho e à situação de matrícula. Do grupo dos desistentes (33,9\%), notou-se que há maior desistência entre os que trabalham, pois representam 66,8\%. Em contrapartida, o índice de estudantes que permanecem com a matrícula ativa e trabalham é de 55,6\%.

Na sequência, destacam-se as proporções da situação de matrícula e a situação de trabalho. 
Gráfico 48 - Situação acadêmica e condição de trabalho dos ingressantes

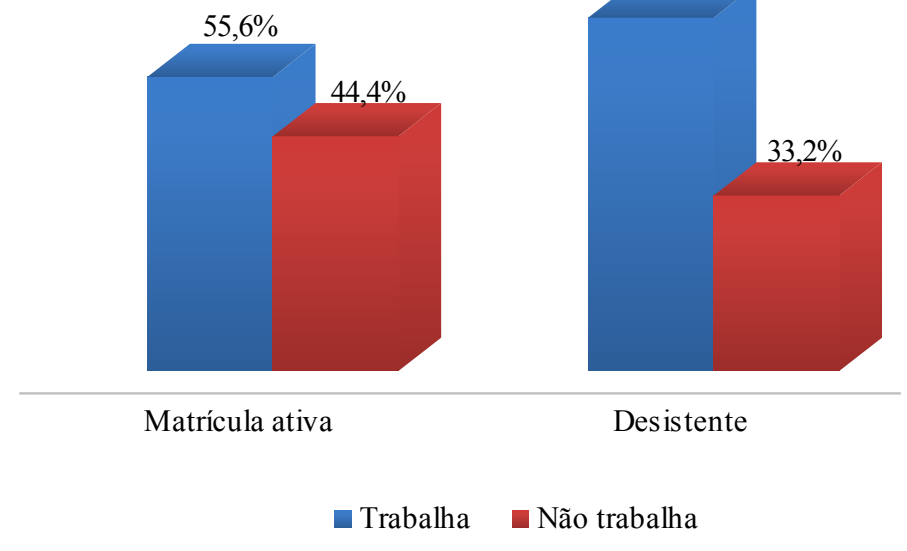

Fonte: Banco de Dados do Processo Seletivo 2012, DRA/PROGRAD/UFFS.

No que tange à condição de renda familiar, conforme apresenta o próximo gráfico, percebe-se que há uma incidência maior de desistência entre o grupo de estudantes que informaram ter renda de até três salários-mínimos.

Gráfico 49 - Situação acadêmica e renda familiar dos estudantes

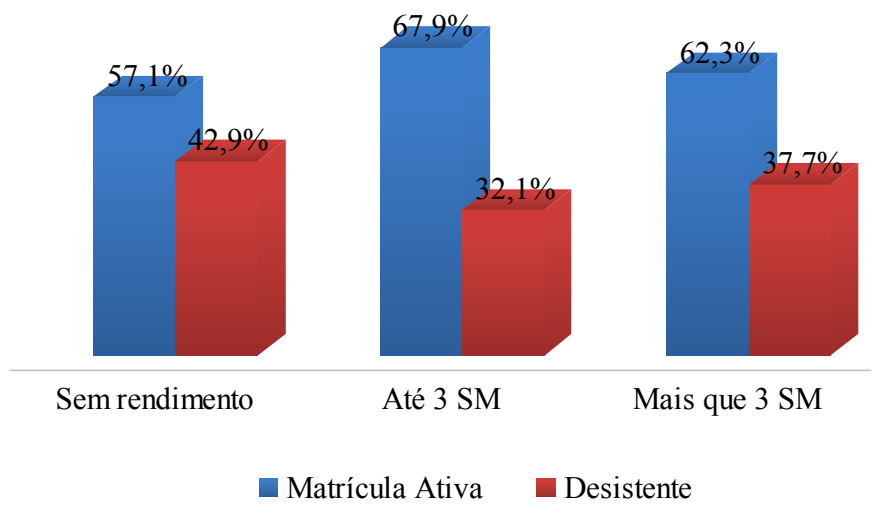

Fonte: Banco de Dados do Processo Seletivo 2012, DRA/PROGRAD/UFFS.

Nota: $\mathrm{SM}$ = salário-mínimo 
Após decorridos dois anos, ao observar a situação de matrícula dos estudantes que ingressaram no ano de 2012, na UFFS, pode-se traçar algumas reflexões sobre as políticas de acesso e a permanência dos estudantes, considerando o seu perfil socioeconômico e suas trajetórias escolares. Segundo Ristoff (2013b, p. 20):

Sendo a origem social e a situação socioeconômica da família do estudante, sem dúvida, fatores determinantes na trajetória do jovem pela educação superior, as políticas de acesso e permanência assumem papel central na inclusão dos grupos historicamente excluídos, em uma trajetória de democratização da universidade brasileira.

É possível, também, estabelecer uma relação entre a pobreza e as desigualdades educacionais. Por isso, é fundamental que as políticas de inclusão das Universidades sejam acompanhadas também de sólidas políticas voltadas para a permanência, pois, segundo Dias Sobrinho (2010), a vulnerabilidade da maioria da população brasileira constitui um dos grandes obstáculos para a "democratização" da educação superior. O autor destaca as contribuições das políticas inclusivas e de expansão da educação superior para a sociedade brasileira, mas aponta também limites, tendo em vista que a desigualdade social da sociedade brasileira se trata de um problema estrutural. Afirma o autor:

Por mais benéficas e necessárias que sejam as políticas de "democratização" da educação superior, por via de ampliação de matrículas e ações afirmativas de inclusão social, apresentam sérios limites que não serão transpostos em curto espaço de tempo. Muito positivo é o fato de que elas contribuem para uma mudança de cultura contrária à permanência perversa do elitismo e do racismo e favorável ao abrandamento das assimetrias sociais (DIAS SOBRINHO, 2010, p. 1.237).

Para Velloso (2011, p. 406), “o conceito de democratização do acesso que cremos apropriado considera um ritmo do aumento de vagas acima 
da taxa de crescimento da faixa etária pertinente e considera processos de inclusão social".

Ao refletir sobre as políticas de acesso à educação superior e de permanência, cumpre registrar que a UFFS, desde o seu primeiro ano de atividades acadêmicas, mais especificamente a partir do segundo semestre de 2010, desenvolve programas de bolsas para auxiliar financeiramente os estudantes na sua permanência, principalmente aqueles em situação de vulnerabilidade socioeconômica. Os principais auxílios ofertados são moradia, alimentação ${ }^{33}$, transporte, material didático e auxílio emergencial.

As ações de assistência estudantil são desenvolvidas com base no Programa Nacional de Assistência Estudantil. Sua gestão e operacionalização é realizada por meio da Pró-Reitoria de Assuntos Estudantis e pelos Setores de Assuntos Estudantis (SAEs) nos campi da Universidade. Também são oferecidos outros serviços, como apoio pedagógico e psicológico aos estudantes, ações nas áreas de cultura e esporte.

Além dos recursos provindos do PNAES, em maio de 2013, o MEC lançou o Programa Bolsa Permanência (PBP), com o objetivo de abranger estudantes em situação de vulnerabilidade, com uma bolsa de R \$400,00 mensais, e os estudantes indígenas e quilombolas, com uma bolsa no valor de R \$900,00, com abrangência a todas as instituições federais de educação superior. Os valores são transferidos diretamente aos estudantes, por meio de um cartão de benefício, desde que atendam aos critérios estabelecidos para o programa. Um desses critérios é a matrícula em cursos de graduação que tenham uma carga horária média superior ou igual a 5 horas diárias. No caso específico da UFFS, o curso de Medicina foi o único que se enquadrou nos termos de exigência da carga horária. Aos estudantes indígenas e quilombolas não existe essa exigência de carga horária, sendo-lhes possível acessar a bolsa, respeitados os demais critérios (BRASIL, 2014b).

33 A UFFS, em sua estrutura possui em cada campus um Restaurante Universitário (RU). Somente no Campus de Chapecó, o RU, já está em funcionamento com a oferta de almoço e jantar. 
Além das questões relacionadas ao apoio financeiro, sendo este fundamental para apoiar a permanência de estudantes universitários, os dados chamam a atenção para a necessidade de aprofundar também questões relacionadas ao sucesso e insucesso escolar. De acordo com os autores Costa et al. $(2014$, p. 6$)$ :

[...] a promoção do sucesso escolar no ensino superior não pode deixar de ser considerada atualmente um objetivo fundamental de políticas públicas e da ação das instituições universitárias e politécnicas. Por sua vez, o insucesso e o abandono escolar não podem deixar de ser considerados problemas preocupantes, quer para os estudantes diretamente afetados, quer para o sistema de ensino superior, quer ainda para a sociedade no seu conjunto.

Costa et al. (2014) salientam a importância que o primeiro ano de frequência ao ensino superior assume e pode ser até determinante para a permanência ou a desistência desse nível de ensino, pois é nesse período que surgem as maiores dificuldades de adaptação e integração no contexto universitário.

Ainda sobre essa questão, o relatório sobre "Evasão/Ocupação nos cursos de graduação da UFFS”, realizado pelo Grupo de Pesquisa em Educação Popular (GRUPEPU) da Universidade, aponta algumas reflexões acerca do conceito de evasão na educação superior, partindo das contradições que se apresentam num cenário marcado, de um lado, pela democratização do acesso da educação superior às camadas populares e, de outro, pela continuidade da privatização da Educação e pela falta de políticas que promovam a permanência e a conclusão dos estudos. Conforme o estudo (UFFS, 2014b, p. 16), “[...] avançamos na ampliação do acesso ao Ensino Superior, mas nos certificamos da problemática do alto índice de evasão e retenção de estudantes (pela reprovação ou pela frequência)". 
O Relatório, ao apresentar dados sobre a questão da evasão na UFFS, do ano de 2010 até o primeiro semestre do ano de $2014^{34}$, considera como "Taxa de Evasão": “[...] os alunos que entraram de fato na universidade e quantos deles ainda estão na instituição, sendo que para aqueles cursos que já tiveram egressos, esses foram somados aos vinculados para se ter um panorama da série histórica do curso" (UFFS, 2014b, p. 20). No ano de 2010, a taxa de evasão foi de 51\%. Em 2011, esse percentual reduziu para $49 \%$. Em 2012, o percentual foi de $40 \%$ e, em 2013, o percentual diminuiu para $30 \%$. Esses indicadores sinalizam percentuais altos de estudantes que ingressaram e não mais permanecem na Instituição. Conforme análise do GRUPEPU (UFFS, 2014b, p. 56), “[...] fica enunciada claramente o alto percentual médio de evasão, o qual dificilmente fica abaixo de $30 \%$, ou seja, cerca de um terço dos ingressantes se evadem de alguma forma dos cursos de graduação".

Conforme Ristoff (2013a), ao avaliar a questão do sucesso escolar, a partir dos concluintes nos cursos de graduação no Brasil, finaliza que cerca de $60 \%$ dos ingressantes concluem seus estudos. Ao analisar os dados do INEP sobre essa questão, no período de 1991 a 2011, constata que "[...] as gerações mais recentes vêm enfrentando mais dificuldades para se graduarem, chegando em 2011 com uma taxa de sucesso de apenas 44\%" (RISTOFF, 2013a, p. 40). O autor chama a atenção para a Região Sul, que, desde 1994, mantém a menor taxa de sucesso e chega, em 2011, com apenas $39 \%$ dos estudantes concluindo os estudos num período de quatro anos.

A rede privada de ensino superior é a que mais forma estudantes. Com base em Ristoff (2013a, p. 43):

Em 2011, não obstante todos os programas de expansão das universidades públicas federais e a expansão da rede de institutos federais, o setor privado responde por $79 \%$ dos concluintes da graduação, tendo sido a educação privada, nas últimas duas décadas, 
a principal responsável pela formação dos profissionais de nível superior no país.

Observa-se que o fenômeno do insucesso escolar está presente em todas as IES brasileiras e, ao olhar de modo especial para a UFFS, depara-se com um paradoxo: de um lado, suas políticas de acesso demonstram inclusão e inovação e, de outro, há significativos percentuais de estudantes que não permanecem.

Trata-se de uma realidade muito complexa e que precisa de uma atenção por parte da Universidade, tendo em vista o seu compromisso com a inclusão e a permanência de uma camada populacional que, historicamente, esteve excluída do acesso à educação superior pública. Conforme verificado pelo perfil socioeconômico dos ingressantes, é visível que ocorreu uma verdadeira inclusão, a partir das políticas de acesso adotadas pela Universidade, porém, fazem-se necessárias políticas efetivas para que não ocorram novos processos de exclusão após o ingresso desses jovens universitários. Tais políticas devem promover ações voltadas a apoiar a permanência dos estudantes por meio da assistência estudantil e de outras dimensões da vida universitária, como a sociabilidade, a adaptação e o apoio à aprendizagem.

Como destaca Dubet (2008), a expansão/massificação da educação superior introduziu novos desafios para as instituições e para as políticas educacionais. Os grupos sociais não se beneficiam das políticas de acesso da mesma maneira. Além disso, os indivíduos não são iguais. As diferenças precisam ser consideradas. De acordo com o autor, é necessário “[...] desenvolver a igualdade distributiva das oportunidades, isto é, zelar pela equidade da oferta escolar, às vezes dando mais aos menos favorecidos, de qualquer maneira tentando atenuar os efeitos mais brutais de uma competição pura” (DUBET, 2008, p. 12). As oportunidades precisam ser distribuídas de forma justa. 